\title{
Soluble Tumor Necrosis Factor Alpha Promotes Retinal Ganglion Cell Death in Glaucoma via Calcium-Permeable AMPA Receptor Activation
}

\author{
Jorge L. Cueva Vargas, ${ }^{1}$ Ingrid K. Osswald, ${ }^{2}$ Nicolas Unsain, ${ }^{3}$ Mark R. Aurousseau, ${ }^{2}$ Philip A. Barker, ${ }^{3}$ Derek Bowie, ${ }^{2}$ \\ and Adriana Di Polo ${ }^{1}$ \\ ${ }^{1}$ Department of Neuroscience and University of Montreal Hospital Research Center (CRCHUM), University of Montreal, Montreal, Quebec H2X 0A9, \\ Canada, ${ }^{2}$ Department of Pharmacology and Therapeutics, McGill University, Montreal, Quebec H3G 1Y6, Canada, and ${ }^{3}$ Centre for Neuronal Survival, \\ Montreal Neurological Institute, Montreal, Quebec H3A 2B4, Canada
}

Loss of vision in glaucoma results from the selective death of retinal ganglion cells (RGCs). Tumor necrosis factor $\alpha$ (TNF $\alpha$ ) signaling has been linked to RGC damage, however, the mechanism by which TNF $\alpha$ promotes neuronal death remains poorly defined. Using an in vivo rat glaucoma model, we show that TNF $\alpha$ is upregulated by Müller cells and microglia/macrophages soon after induction of ocular hypertension. Administration of XPro1595, a selective inhibitor of soluble TNF $\alpha$, effectively protects RGC soma and axons. Using cobalt permeability assays, we further demonstrate that endogenous soluble TNF $\alpha$ triggers the upregulation of $\mathrm{Ca}^{2+}$-permeable AMPA receptor (CP-AMPAR) expression in RGCs of glaucomatous eyes. CP-AMPAR activation is not caused by defects in GluA2 subunit mRNA editing, but rather reflects selective downregulation of GluA2 in neurons exposed to elevated eye pressure. Intraocular administration of selective CP-AMPAR blockers promotes robust RGC survival supporting a critical role for non-NMDA glutamate receptors in neuronal death. Our study identifies glia-derived soluble TNF $\alpha$ as a major inducer of RGC death through activation of CP-AMPARs, thereby establishing a novel link between neuroinflammation and cell loss in glaucoma.

Key words: AMPA receptor; calcium; glaucoma; neuroinflammation; retinal ganglion cell; tumor necrosis factor

Significance Statement

Tumor necrosis factor $\alpha$ (TNF $\alpha$ ) has been implicated in retinal ganglion cell (RGC) death, but how TNF $\alpha$ exerts this effect is poorly understood. We report that ocular hypertension, a major risk factor in glaucoma, upregulates TNF $\alpha$ production by Müller cells and microglia. Inhibition of soluble TNF $\alpha$ using a dominant-negative strategy effectively promotes RGC survival. We find that TNF $\alpha$ stimulates the expression of calcium-permeable AMPA receptors (CP-AMPAR) in RGCs, a response that does not depend on abnormal GluA2 mRNA editing but on selective downregulation of the GluA2 subunit by these neurons. Consistent with this, CP-AMPAR blockers promote robust RGC survival supporting a critical role for non-NMDA glutamate receptors in glaucomatous damage. This study identifies a novel mechanism by which glia-derived soluble TNF $\alpha$ modulates neuronal death in glaucoma.

\section{Introduction}

Glaucoma is the leading cause of irreversible blindness worldwide affecting $>60$ million people (Tham et al., 2014). The disease is characterized by progressive optic nerve degeneration resulting in vision loss. A crucial element in the pathophysiology

Received April 2, 2015; revised July 1, 2015; accepted July 13, 2015.

Author contributions: J.L.C.V., I.K.O., N.U., M.R.A.,P.A.B., D.B., and A.D.P. designed research; J.L.C.V., I.K.O., N.U., and M.R.A. performed research; J.L.C.V., I.K.O., N.U., M.R.A., P.A.B., D.B., and A.D.P. analyzed data; J.L.C.V., P.A.B., D.B., and A.D.P. wrote the paper.

This work was supported by a team grant from the Canadian Institutes of Health Research (CIHR-VIH-105439); A.D.P. is a Chercheur National of Fonds de recherche Québec-Santé (FRQS). We thank Dr David Szymkowski (Xencor) for providing XPro1595, and Drs Ray Tesi (FPRT Bio) and Timothy Kennedy (McGill University) for helpful comments on the paper. of all forms of glaucoma is the death of retinal ganglion cells (RGCs), the neurons that convey visual information from the retina to the brain. High intraocular pressure has been identified as a major risk factor for developing the disease, but the mechanism by which elevated pressure injures RGCs is unknown. There

The authors declare no competing financial interests.

Correspondence should be addressed to Dr. Adriana Di Polo, Department of Neuroscience, University of Montreal, CRCHUM, 900 Rue Saint-Denis, Tour Viger, Room R09.720, Montreal, QC H2X OA9, Canada. E-mail: adriana.di.polo@umontreal.ca.

N. Unsain's present address: Laboratorio de Neurobiología, Instituto de Investigación Médica Mercedes y Martín Ferreyra, INIMEC-Consejo Nacional de Investigaciones Científicas y Técnicas, Universidad Nacional de Córdoba, Friuli 2434, Córdoba, 5016, Argentina.

DOI:10.1523/JNEUROSCI.1273-15.2015

Copyright $\odot 2015$ the authors $\quad 0270-6474 / 15 / 3512088-15 \$ 15.00 / 0$ 
is no cure for glaucoma and the standard of care is to lower eye pressure by medication or surgery. Many patients, however, continue to experience visual field loss even when pressure lowering treatments are implemented (Caprioli, 1997; Georgopoulos et al., 1997). A better understanding of the mechanisms involved in glaucomatous neurodegeneration triggered by ocular hypertension injury is, therefore, essential to develop effective therapeutics.

Recent data demonstrate a neuroinflammatory component in glaucoma characterized by upregulation of proinflammatory cytokines, most notably tumor necrosis factor $\alpha$ (TNF $\alpha$; Tezel, 2013; Soto and Howell, 2014). TNF $\alpha$ is a pleiotropic cytokine with physiological and pathological functions that include regulation of inflammation, innate immunity, cancer, synaptic function, and neurogenesis (Marin and Kipnis, 2013). TNF $\alpha$ is produced as a $22 \mathrm{kDa}$ membrane-bound precursor that is cleaved by ADAM-17 (a disintegrin and metalloproteinase-17) to release the soluble $17 \mathrm{kDa}$ mature TNF $\alpha$ (Moss et al., 1997). Both the transmembrane and soluble forms of TNF $\alpha$ are active and play distinct biological roles (Alexopoulou et al., 2006). Soluble TNF $\alpha$ binds primarily to TNFR1, and mediates apoptosis and chronic inflammation (Holtmann and Neurath, 2004; Brambilla et al., 2011; Novrup et al., 2014), whereas membrane-bound TNF $\alpha$ displays higher affinity for TNFR2 and regulates immunity against pathogens, resolution of inflammation, and myelination (Pasparakis et al., 1996; Arnett et al., 2001; Canault et al., 2004; Olleros et al., 2005; Alexopoulou et al., 2006; Ierna et al., 2009). Consistent with this, mice expressing only transmembrane TNF $\alpha$ suppress the onset and progression of autoimmune demyelination while maintaining host defenses against bacterial infection, septic shock, and pulmonary fibrosis (Mueller et al., 1999; Olleros et al., 2002; Alexopoulou et al., 2006; Oikonomou et al., 2006).

TNF $\alpha$ signaling is linked to RGC damage. Exogenous administration of TNF $\alpha$ promotes RGC loss and optic nerve degeneration (Nakazawa et al., 2006; Lebrun-Julien et al., 2009b) and RGCs lacking TNFR1 are protected from mechanical injury (Tezel et al., 2004). TNFR2 deficiency was associated with increased RGC loss during retinal ischemia (Fontaine et al., 2002), yet lack of TNFR2 has been reported to protect RGCs from ocular hypertension damage (Nakazawa et al., 2006). The differential affinity of soluble versus transmembrane TNF $\alpha$ for its receptors, as well as the timing of injury-related TNF $\alpha$ signaling (Mac Nair et al., 2014) may underlie these disparate data. Recently, highthroughput characterization of the retinal proteome revealed prominent upregulation of TNF $\alpha /$ TNFR1 signaling in human glaucoma (Yang et al., 2011). Notably, TNF $\alpha$ levels are elevated in aqueous humor samples from glaucoma patients (Sawada et al., 2010; Balaiya et al., 2011) and TNF $\alpha$ gene polymorphisms are associated with primary open angle glaucoma (Xin et al., 2013). Despite these correlative data, the mechanism by which TNF $\alpha$ promotes RGC death is poorly understood.

TNF $\alpha$ exerts homeostatic control of synaptic strength by regulating AMPA receptor (AMPAR) trafficking in the CNS (Pribiag and Stellwagen, 2014). Administration of exogenous TNF $\alpha$ to hippocampal neuron cultures induces cell surface expression of GluA2-lacking AMPARs, which are calcium $\left(\mathrm{Ca}^{2+}\right)$-permeable (Beattie et al., 2002; Ogoshi et al., 2005; Stellwagen et al., 2005; Stellwagen and Malenka, 2006). Moreover, TNF $\alpha$-induced expression of $\mathrm{Ca}^{2+}$-permeable-AMPARs (CP-AMPARs) exacerbates neuronal death during acute ischemia and excitotoxicity (Ferguson et al., 2008; Leonoudakis et al., 2008; Lebrun-Julien et al., 2009b; Yin et al., 2012). In this study, we investigated whether soluble TNF $\alpha$ is an effector of RGC death and its mechanism of action in a rat glaucoma model. Our data reveal that ocular hypertension stimulates production of glia-derived soluble TNF $\alpha$, which triggers RGC surface expression of CP-AMPAR contributing to neuronal death.

\section{Materials and Methods}

Experimental animals. All procedures were performed in male Brown Norway rats (300-400 g; Charles River Laboratories) in compliance with the guidelines of the Canadian Council on Animal Care for the Use of Experimental Animals (http://www.ccac.ca). The number of animals used in each experiment is indicated in the corresponding figure legend and the tables.

Ocular hypertension. Unilateral elevation of intraocular pressure was induced by injection of hypertonic saline solution into an episcleral vein as previously described (Morrison model; Morrison et al., 1997; Almasieh et al., 2010). Briefly, a plastic ring was applied to the ocular equator to confine the injection to the limbal plexus and a microneedle was used to inject $50 \mu \mathrm{l}$ of sterile $1.85 \mathrm{M} \mathrm{NaCl}$ through an episcleral vein. Following injection, the plastic ring was removed and the eyes were examined to assess the extent to which the saline solution traversed the limbal microvasculature. Polysporin ophthalmic ointment (Pfizer) was applied to the operated eye and the animal was allowed to recover. Eye pressure measurements were taken from awake animals after corneal application of one drop of proparacaine hydrochloride $(0.5 \%$, Alcon Laboratories) using a calibrated tonometer (TonoPen XL; Medtronic Solan). The tonometer was held perpendicular to the corneal surface and 10 consecutive readings per eye were taken and averaged. Intraocular pressure was measured every other day, at the same time, for the entire duration of the experiment. The mean and peak (maximum) intraocular pressure values for each eye were calculated and used to estimate the mean and peak pressure for experimental and control groups.

Drug delivery. The following compounds were injected into the vitreous chamber in a total volume of $5 \mu$ l using a Hamilton syringe adapted with a 32 gauge glass microneedle: XPro1595 (50 $\mu \mathrm{g} / \mu \mathrm{l}$, Xencor), GYKI 52466 (250 $\mu \mathrm{M}$, Tocris Bioscience), or Philantotoxin 343 (PhTx 343; 250 $\mu \mathrm{M}$, Sigma-Aldrich). Control animals received sterile PBS vehicle. The tip of the needle was inserted into the superior hemisphere of the eye at a $\sim 45^{\circ}$ angle through the sclera into the vitreous body to avoid retinal detachment or injury to eye structures. Surgical glue (Indermill, Tyco Health Care) was used to seal the injection site.

Quantification of RGC soma and axons. Before induction of ocular hypertension, RGCs were retrogradely labeled with the indocarbocyanine dye DiI (1,1'-dioctadecyl-3,3,3',3' -tetramethyl-indocarbocyanine perchlorate; Invitrogen) prepared by dissolving crystals (3\%) in $0.9 \%$ $\mathrm{NaCl}$. The superior colliculus was exposed and a small piece of gelfoam (GE Healthcare and Upjohn) soaked in tracer was applied to the surface. For RGC density counts, rats were deeply anesthetized and perfused transcardially with $4 \%$ paraformaldehyde (PFA), the retinas were dissected out and flat-mounted on a glass slide with the ganglion-cell layer side up. DiI-labeled RGCs were counted in three square areas at 1, 2, and $3 \mathrm{~mm}$ from the optic disc in each retinal quadrant for a total of 12 retinal areas encompassing a total area of $1 \mathrm{~mm}^{2}$. Macrophages and microglia that incorporated DiI after phagocytosis of dying RGCs were excluded from our quantitative analysis (Lebrun-Julien et al., 2009a). For axon counts, animals received a transcardial injection of heparin $(1000 \mathrm{u} / \mathrm{kg})$ and sodium nitroprusside $(10 \mathrm{mg} / \mathrm{kg}$ ) followed by perfusion with $2 \%$ PFA and $2.5 \%$ glutaraldehyde in $0.1 \mathrm{~m}$ PBS. Optic nerves were dissected, fixed in $2 \%$ osmium tetroxide, and embedded in epon resin. Semithin sections $(0.7 \mu \mathrm{m})$ were cut on a microtome (Reichert) and stained with $1 \%$ toluidine blue. Images were acquired using an oil-immersion $63 \times$ objective (numerical aperture: 1.4 ) with an additional microscope eyepiece magnification of $2.5 \times$ for a total visual magnification of $157.5 \times$. RGC axons were counted at $1 \mathrm{~mm}$ from the optic nerve head in five nonoverlapping areas of each optic nerve section, encompassing a total area of $5500 \mu \mathrm{m}^{2}$ per nerve. The five optic nerve areas analyzed included: one in the center of the nerve, two peripheral dorsal, and two peripheral ventral regions. The total area per optic nerve cross-section was measured using Northern Eclipse image analysis software (Empix Imaging), 


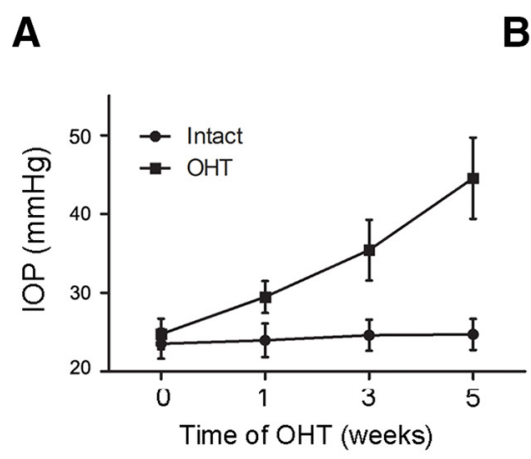

D
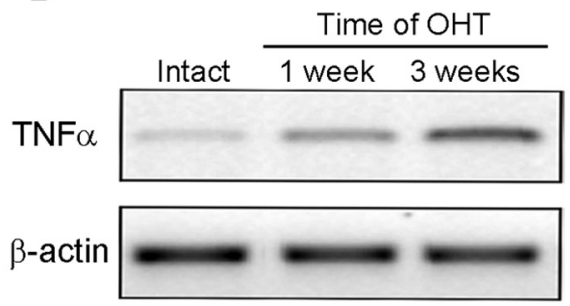

F

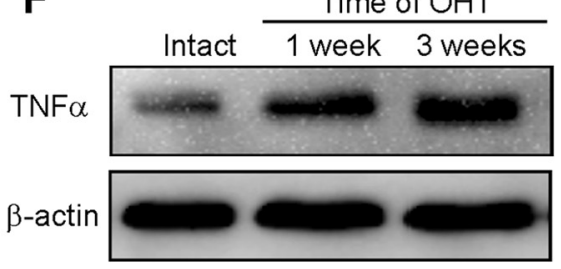

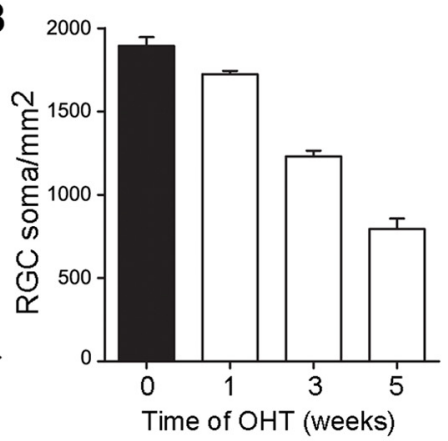
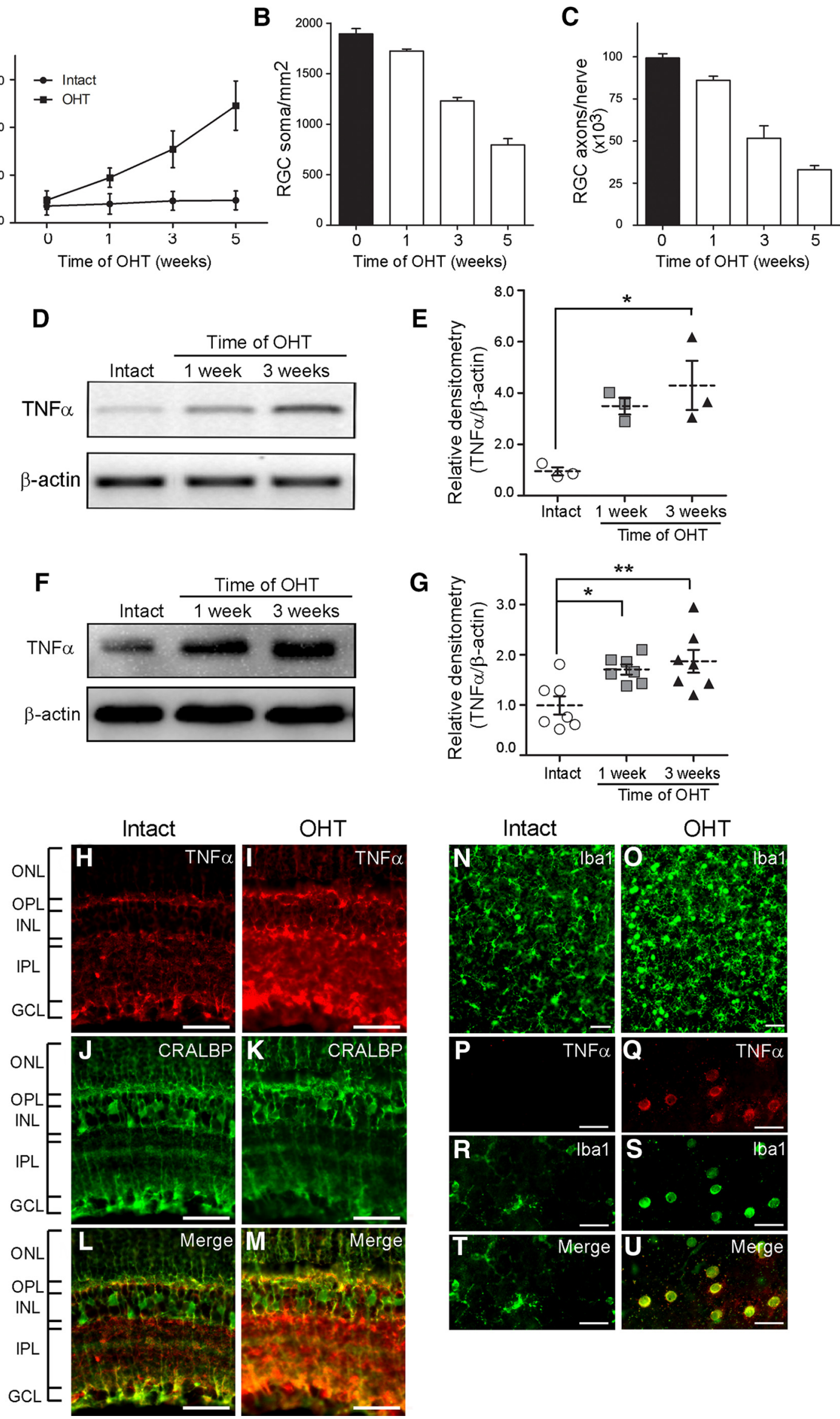
and this value was used to estimate the total number of axons per optic nerve.

Retinal immunohistochemistry. Animals were perfused transcardially with $4 \%$ PFA and retinal cryosections $(16 \mu \mathrm{m})$ were prepared. The following primary antibodies were added to the retinal sections in blocking solution and incubated overnight at $4^{\circ} \mathrm{C}$ : TNF $\alpha(0.4 \mu \mathrm{g} / \mathrm{ml}$; Millipore $)$, cellular retinaldehyde-binding protein (CRALBP; $1 \mu \mathrm{g} / \mathrm{ml}$; ThermoFisher Scientific), TNFR1 (2 $\mu \mathrm{g} / \mathrm{ml}$, Hycult Biotech), TNFR2 $(1.5 \mu \mathrm{g} / \mathrm{ml}$, Antibodies On-line), RNA-binding protein with multiple splicing (RBPMS; $0.01 \mu \mathrm{g} / \mathrm{ml}$, PhosphoSolutions), glial fibrillary acidic protein (GFAP; $1 \mu \mathrm{g} / \mathrm{ml}$, Millipore), choline acetyltransferase (ChAT; $1 \mu \mathrm{g} / \mathrm{ml}$, Millipore), or GluA2 (6C4, $2 \mu \mathrm{g} / \mathrm{ml}$, Millipore). Sections were washed and incubated with secondary antibodies: anti-rabbit IgG $(1 \mu \mathrm{g} / \mathrm{ml}$, Cy3; Jackson ImmunoResearch) or anti-mouse IgG ( $1 \mu \mathrm{g} / \mathrm{ml}$, FITC; SigmaAldrich). For whole-mount immunostaining, retinas were incubated at $-80^{\circ} \mathrm{C}$ for $15 \mathrm{~min}$, and then overnight at $4^{\circ} \mathrm{C}$ in blocking solution $(2 \%$ normal donkey serum, 2\% Triton X-100 in PBS) containing an antibody against ionized calcium-binding adaptor molecule 1 (Ibal; $1.5 \mu \mathrm{g} / \mathrm{ml}$, Wako Pure Chemicals) and TNF $\alpha$ ( $4 \mu \mathrm{g} / \mathrm{ml}, \mathrm{R} \& D$ Systems), followed by secondary donkey anti-rabbit IgG AlexaFluor 594 and anti-mouse IgG AlexaFluor 488 (6 $\mu \mathrm{g} / \mathrm{ml}$, Invitrogen). Retinas were mounted on glass slides using an antifade reagent (Invitrogen) for visualization with a Zeiss AxioSkop 2 Plus microscope (Carl Zeiss).

Semiquantitative $R T-P C R$ and $Q / R$ site editing assay. Total RNA was isolated from individual retinas using the RNeasy Plus Mini kit (Qiagen) according to the manufacturer's instructions. First-strand cDNA synthesis was performed using SuperScript III First-Strand Synthesis System (Life Technologies) and oligo (dT) ${ }_{20}$ primers. PCR was performed using the following primers (300 nM): TNF $\alpha$ forward: 5'-TCCCAACAAG GAGGAGAAGTTCCC-3', TNF $\alpha$ reverse: $5^{\prime}$-AATGGCAAATCGGCT GACGGTG-3', TNFR1 forward: 5'-ACCCCGGCTTCAACCCCACT3', TNFR1 reverse: 5'-GGGTCTGCAGTGTCAAGCCGT-3', TNFR2 forward: $5^{\prime}$-GTGCAGGCCCCACCGCATTT-3', TNFR2 reverse: $5^{\prime}$ TGGGCCTCCGCTGTGACTCT-3', GluA2 forward: 5' -CTATTTCCA AGGGGCGCTGAT-3', GluA2 reverse: 5' -CAGTCCAGGATTACACGC CG-3', $\beta$-actin forward: $5^{\prime}$-CACCACTTTCTACAATGAGC-3', and $\beta$-actin reverse: $5^{\prime}$-CGGTCAGGATCTTCATGAGG-3'. To assess Q/R site editing, the GluA2 open reading frame containing the $Q / R$ site was amplified using the following: forward (5'-GAATGGTATGGTTGG AGAGC- $3^{\prime}$ ) and reverse ( $5^{\prime}$-CACTT TCGATGGGAGACAC- $3^{\prime}$ ) primers. The expected $527 \mathrm{bp}$ amplicon was obtained using a forward nested primer (5'-GCACACTGAGGAATTTGAAG-3') and an identical reverse primer resulting in a smaller 254 bp product, which was purified (MinElute; Qiagen) and digested with $B b v l$ (New England Biolabs). The reaction products were separated on agarose gels and visualized using a GelDoc imaging system (Biorad). Densitometry was performed using ImageJ software (http://imagej.nih.gov) and the purified PCR products were sequenced (McGill University and Génome Québec Innovation Centre, QC).

$\leftarrow$

Figure 1. TNF $\alpha$ mRNA and protein are rapidly upregulated in experimental glaucoma. $A$, IOP increased gradually after hypertonic saline injection into an episcleral vein. $B, C, 0$ cular hypertension (OHT) led to progressive loss of RGC soma and axons. D, RT-PCR analysis of glaucomatous retinas showed rapid TNF $\alpha$ mRNA upregulation after $\mathrm{OHT}$ induction compared with intact controls. E, Densitometry analysis of amplification products with respect $\beta$-actin controls loaded in the same gel, confirmed TNF $\alpha$ gene expression upregulation in glaucoma $(n=3$, ANOVA, $\left.{ }^{*} p<0.05\right)$. $\boldsymbol{F}$, Analysis of protein homogenates showed that retinal TNF $\alpha$ levels increased at 1 and 3 weeks after $\mathrm{OHT}$ induction. Bottom, The same blot but probed with an antibody that recognizes $\beta$-actin to confirm equal protein loading. $\mathbf{G}$, Densitometry analysis of Western blots showing the ratio of TNF $\alpha$ relative to $\beta$-actin $\left(n=7\right.$, ANOVA, ${ }^{*} p<0.05$, ${ }^{* *} p<$ 0.01). $\boldsymbol{H}-\boldsymbol{M}$, Immunohistochemistry using antibodies against TNF $\alpha$ and CRALBP, a Müller cellspecific marker, demonstrated that these glial cells upregulate TNF $\alpha$ soon after glaucoma induction. $\mathbf{N}-\boldsymbol{U}$, Analysis of the inner plexiform layer on whole-mounted retinas revealed that presumptive microglia/macrophages, visualized with Iba1, are a source of TNF $\alpha$ in glaucoma. Representative images from whole-mounted retinas were sampled from the superior, central quadrant located at $1 \mathrm{~mm}$ from the optic disk. Scale bars, $50 \mu \mathrm{m}$. ONL, Outer nuclear layer; OPL: outer plexiform layer.
Subcellular fractionation and Western blot analyses. Whole retinas were isolated and homogenized in fractionation buffer: $250 \mathrm{~mm}$ sucrose, 20 mM HEPES, pH 7.4, $10 \mathrm{~mm} \mathrm{KCl}, 1.5 \mathrm{~mm} \mathrm{MgCl}, 1 \mathrm{~mm}$ EDTA, and $1 \mathrm{~mm}$ EGTA supplemented with protease inhibitors. Samples were centrifuged for $13 \mathrm{~min}$ at $8700 \times g$ to separate the nuclear fraction. The supernatant was centrifuged for an additional $6 \mathrm{~min}$ and $40 \mathrm{~s}$ at $43,000 \times g$ to separate the mitochondria and lysosomal fraction (pellet). The supernatant containing the total membrane and cytosolic fractions was further centrifuged for $1 \mathrm{~h}$ at $110,000 \times g$; the pellet was resuspended in fractionation buffer. Retinal samples not subjected to fractionation were homogenized with an electric pestle (Kontes) in ice-cold lysis buffer: $50 \mathrm{~mm}$ Tris, $\mathrm{pH}$ $7.4,150 \mathrm{~mm} \mathrm{NaCl}, 1 \% \mathrm{NP}-40,5 \mathrm{~mm}$ Na fluoride, $0.25 \% \mathrm{Na}$ deoxycholate, and $2 \mathrm{nM} \mathrm{NaVO}_{3}$ supplemented with protease and phosphatase inhibitors. Samples were separated in 7.5-15\% SDS-PAGE and transferred to nitrocellulose membranes (Bio-Rad). Blots were incubated overnight at $4^{\circ} \mathrm{C}$ in blocking buffer ( $10 \mathrm{~mm}$ Tris, $\mathrm{pH} 8.0,150 \mathrm{~mm} \mathrm{NaCl}, 0.1 \%$ Tween 20 , and $5 \%$ bovine serum albumin) containing each of the following primary antibodies: TNF $\alpha$ (1 $\mu \mathrm{g} / \mathrm{ml}$ R\&D Systems), TNFR1 $(2 \mu \mathrm{g} / \mathrm{ml}$, Hycult Biotech), TNFR2 ( $1 \mu \mathrm{g} / \mathrm{ml}$, Antibodies On-line), GluA2 $(4 \mu \mathrm{g} /$ $\mathrm{ml}$; Abcam $), \mathrm{Na}^{+} / \mathrm{K}^{+}$ATPase $(0.1 \mu \mathrm{g} / \mathrm{ml}$, Thermo Scientific), glyceraldehyde 3 phosphate dehydrogenase (GAPDH; $0.5 \mu \mathrm{g} / \mathrm{ml}$, Cedarlane), or $\beta$-actin $(0.5 \mu \mathrm{g} / \mathrm{ml}$; Sigma-Aldrich). Membranes were washed and incubated in peroxidase-linked anti-mouse or anti-rabbit secondary antibodies $(0.5 \mu \mathrm{g} / \mathrm{ml}$, GE Healthcare $)$. Blots were developed with a chemiluminescence reagent (GE Healthcare) and exposed to X-OMAT imaging film (Eastman Kodak). Densitometry was performed using ImageJ software on scanned autoradiographic films obtained from a series of three independent Western blots each performed using retinal samples from distinct experimental or control groups.

Cobalt permeability assay. Retinas were dissected out, cut in small pieces, and incubated for $30 \mathrm{~min}$ in oxygenated assay buffer $(5 \mathrm{~mm} \mathrm{KCl}$, $2 \mathrm{~mm} \mathrm{MgCl}, 12 \mathrm{~mm}$ glucose, $20 \mathrm{~mm}$ bicarbonate, $139 \mathrm{~mm}$ sucrose, 57.5 $\mathrm{mm} \mathrm{NaCl}$, and $0.75 \mathrm{mM} \mathrm{CaCl}_{2}$ ). The tissue was then incubated in $5 \mathrm{~mm}$ $\mathrm{CoCl}_{2}$ and $10 \mathrm{~mm}$ L-glutamic acid in the presence or absence of AMPA receptor blockers GYKI 52466 (40 $\mu \mathrm{M}$, Tocris Bioscience) or the polyamine derivative PhTx 343 (50 $\mu \mathrm{M}$, Sigma-Aldrich). Cobalt $\left(\mathrm{Co}^{2+}\right)$ was precipitated with $0.24 \%$ ammonium sulfide, and the retina was then fixed in $0.8 \%$ glutaraldehyde and sections were prepared $(20 \mu \mathrm{m})$. Silver enhancement of the $\mathrm{Co}^{2+}$ sulfide precipitate was performed with the GE Healthcare Intense kit, and then retinal sections were rinsed, mounted, and imaged with a Zeiss Axioplan 2 imaging microscope.

Statistical analyses. Data analysis and statistics were performed using the GraphPad Instat software by a one-way ANOVA, followed by the Tukey's multiple-comparison post hoc test, or by a Student's $t$ test as indicated in the legends.

\section{Results}

\section{TNF $\alpha$ and its receptors are rapidly upregulated in experimental glaucoma}

Unilateral ocular hypertension was induced in Brown Norway rats by a single injection of hypertonic saline into an episcleral vein as described previously (Almasieh et al., 2010, 2013). This procedure leads to blockade of aqueous humor outflow, gradual increase of eye pressure and selective loss of RGC soma and axons (Fig. 1A-C). Using this model system, we first asked whether there are variations in endogenous TNF $\alpha$ levels following glaucoma induction. Because early changes are more likely to play a causative role in RGC loss, our analysis focused on events at 1 and 3 weeks after hypertonic saline injection. Quantitative RT-PCR of retinal samples demonstrated a gradual and significant increase of TNF $\alpha$ mRNA in glaucomatous retinas compared with noninjured controls (intact; Fig. $1 D, E$ ). Similarly, Western blot analysis showed a marked increase in $\mathrm{TNF} \alpha$ protein levels in retinas with high intraocular pressure (Fig. $1 F, G$ ). Immunohistochemistry confirmed that although retinal TNF $\alpha$ was low in control noninjured eyes, it increased substantially with ocular hypertension (Fig. $1 H, I$ ). Colabeling experiments using CRALBP, a Mül- 
A

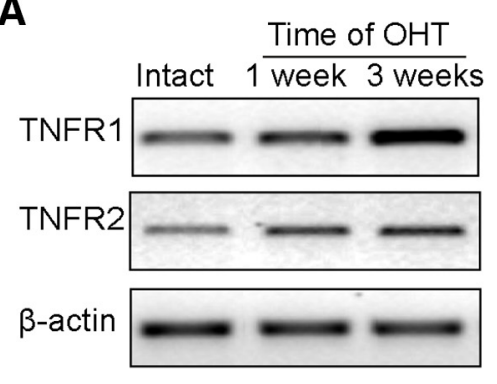

C

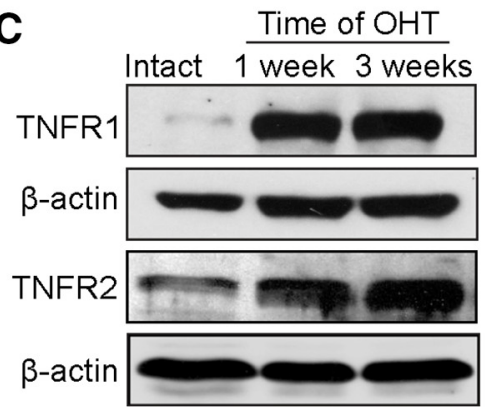

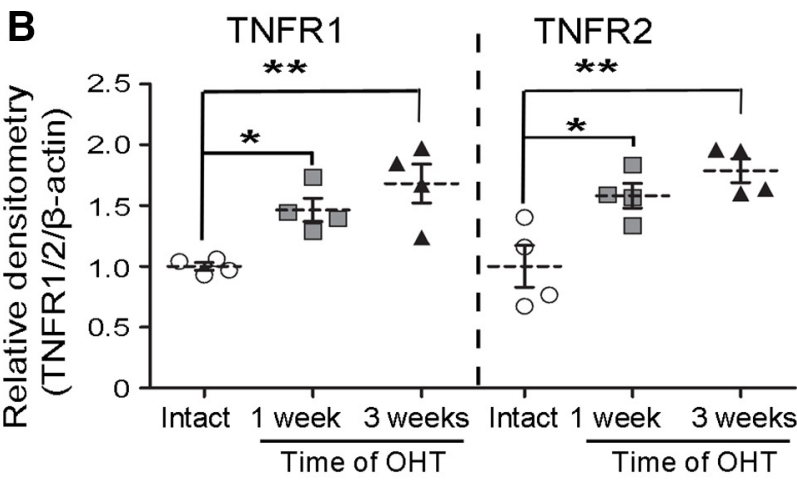

D
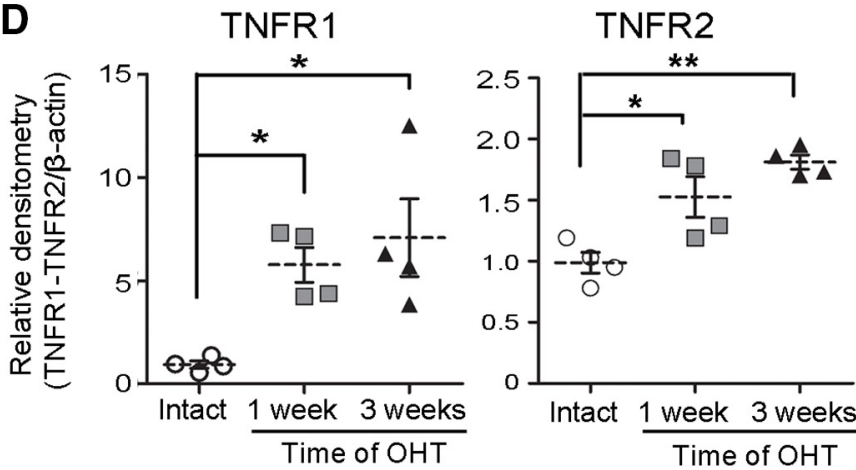

$\mathrm{OHT}$

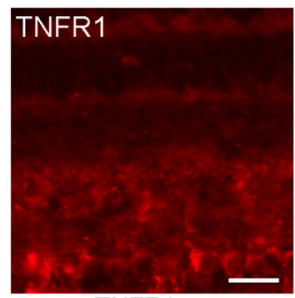

TNFR1

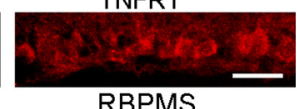

RBPMS

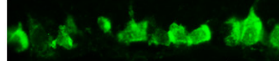

Merge
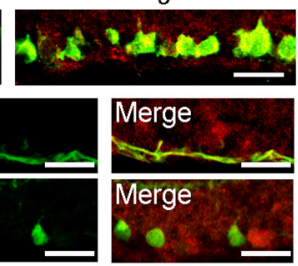

F

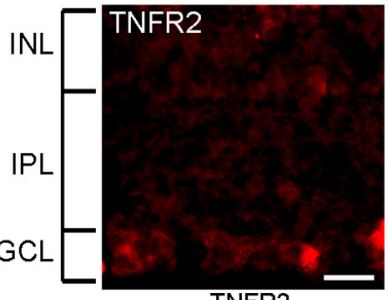

H

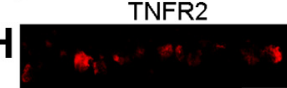

RBPMS

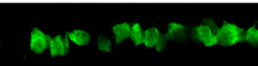

Merge
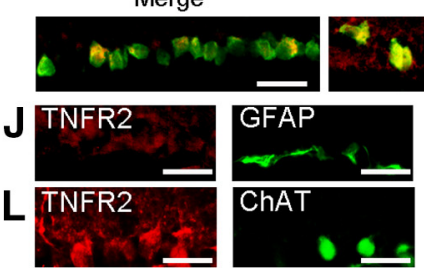

OHT
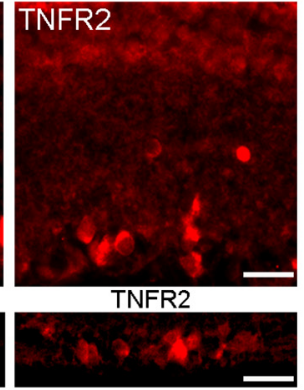

RBPMS

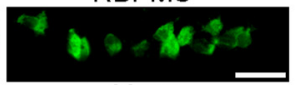

Merge

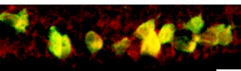

Merge

-2 .

Merge

M

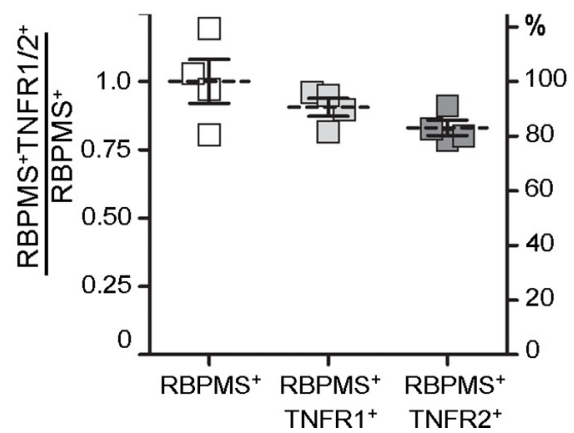


ler cell-specific marker, demonstrated that these glial cells upregulate TNF $\alpha$ soon after glaucoma induction (Fig. $1 J-M$ ). On flat-mounted retinas, analysis of the inner plexiform layer using Iba1, a pan-microglia and macrophage marker (Imai and Kohsaka, 2002), revealed reduced ramifications and increased soma size in Iba1-positive cells suggestive of an activated state during ocular hypertension (Fig. 1 N,O). TNF $\alpha$ was not detected in highly ramified, presumably quiescent, Iba1-positive cells found in noninjured retinas, but increased markedly in cells with round somata and simplified processes (Fig. $1 P-U$ ).

We then asked whether the expression of TNF $\alpha$ receptors, TNFR1 and TNFR2, was altered in this glaucoma model. Our findings reveal an increase of both TNFR1 and TNFR2 mRNA (Fig. $2 A, B$ ) and protein (Fig. 2C,D) detected as early as 1 week after induction of ocular hypertension. Retinal immunohistochemistry confirmed an increase in TNFR1- and TNFR2-positive cells in glaucomatous retinas (Fig. $2 E, F$ ). In the ganglion cell layer, TNFR1 and TNFR2 were upregulated in RGCs, visualized with the RGC-specific marker RBPMS (Fig. 2G,H). In addition to RGCs, displaced amacrine cells and astrocytes populate the ganglion cell layer; therefore, we investigated whether these cells also contained TNF $\alpha$ receptors. Colabeling of TNFR1 with GFAP revealed that some astrocytes express TNFR1 (Fig. 2I), which is consistent with a proteomic analysis of the astrocytic response in experimental glaucoma (Tezel et al., 2012). In contrast, TNFR2 was not detected in GFAP-positive astrocytes (Fig. $2 J$ ). Similarly, amacrine cells in the GCL labeled with ChAT, which represent $20 \%$ of all displaced amacrine cells in the rodent retina (Voigt, 1986; Jeon et al., 1998), did not express TNFR1 or TNFR2 (Fig. $2 K, L)$. Quantification of the number of RGCs labeled with both RBPMS and TNFR1 or TNFR2 with respect to all RBPMSpositive cells in retinal cross sections demonstrated that $91 \%$ and $83 \%$ of RGCs in glaucomatous retinas express TNFR1 or TNFR2, respectively (Fig. 2M). Thus, RBPMS-negative cells expressing either TNFR1 and/or TNFR2 are likely to be astrocytes or a noncholinergic subtype of displaced amacrine cells. We conclude that high intraocular pressure rapidly stimulates TNF $\alpha$ production by retinal glia and increases TNFR1/2 expression in RGCs.

\section{Inhibition of soluble TNF $\alpha$ promotes robust RGC soma and axon protection}

We next sought to test whether soluble TNF $\alpha$ contributes to RGC loss using XPro1595, a dominant-negative protein that selectively inhibits soluble TNF $\alpha$ without interfering with transmembrane TNF $\alpha$ or TNFR (Zalevsky et al., 2007). XPro1595 was injected intraocularly at 1 and 2 weeks after induction of ocular

\section{$\leftarrow$}

Figure 2. Ocular hypertension increases TNFR1 and TNFR2 expression by RGCs. $\boldsymbol{A}$, Rapid upregulation of TNFR1 and TNFR2 mRNA in glaucomatous retinas was detected by RT-PCR. $\boldsymbol{B}$, Densitometry analysis of amplification products with respect to $\beta$-actin control loaded in the same blot confirmed upregulation of TNFR1/2 gene expression $\left(n=4\right.$, ANOVA, ${ }^{*} p<0.05$, $\left.{ }^{* *} p<0.01\right)$. C, Western blot analysis demonstrated increased levels of retinal TNFR1 and TNFR2. Blots were probed with an antibody against $\beta$-actin to confirm equal protein loading. $\boldsymbol{D}$, Densitometry analysis showed increased ratio of TNFR1 or TNFR2 proteins relative to $\beta$-actin in glaucomatous retinas ( $n=4$, ANOVA, ${ }^{*} p<0.05,{ }^{* *} p<0.01$ ). $\boldsymbol{E}, \boldsymbol{F}$, Retinal immunohistochemistry confirmed an increase in TNFR1-and TNFR2-positive cells in glaucomatous retinas. $\boldsymbol{G}$, $\boldsymbol{H}$, In the GCL, TNFR1 and TNFR2 were upregulated in RGCS, visualized with the RGC-specific marker RBPMS. I, J, TNFR1, but not TNFR2, is expressed in some GFAP-positive astrocytes. $\boldsymbol{K}, \boldsymbol{L}$, ChAT-positive displaced amacrine cells do not express TNFR1 or TNFR2. $\boldsymbol{M}$, Quantification of the number of RGCs labeled with both RBPMS and TNFR1 or TNFR2 with respect to all RBPMSpositive cells in retinal cross sections ( $n=4 \mathrm{rats} / \mathrm{group}$ ). Three retinal cross sections per animal were analyzed for a total of 12 retinal sections per group. Scale bars, $50 \mu \mathrm{m}$. hypertension, and RGC survival was evaluated 1 week later (3 weeks after injury onset). Cell soma and axon quantification was performed blinded to treatment. Flat-mounted retinas from eyes treated with XPro1595 showed higher densities of DiI-positive RGCs compared with control retinas treated with vehicle (PBS; Fig. 3A-C). Quantitative analysis demonstrated that XPro1595 promoted significant RGC survival (94\%: $1785 \pm 27$ RGCs/ $\mathrm{mm}^{2}$, mean \pm SEM, $\left.n=7\right)$ with respect to eyes that received vehicle (65\%: $1244 \pm 55 \mathrm{RGCs} / \mathrm{mm}^{2}, n=6$; Fig. $3 G$; Table 1).

To establish whether XPro1595 increased RGC soma survival regionally or throughout the retina, RGC densities were compared in three consecutive areas at $1 \mathrm{~mm}$ (central), $2 \mathrm{~mm}$ (middle), and $3 \mathrm{~mm}$ (peripheral) from the optic nerve head in each retinal quadrant. Although higher RGC densities are typically found in central areas compared with the periphery, XPro1595mediated survival was proportional in all retinal regions accounting for $32 \%$ of all RGCs (Fig. 3E). Collectively, these data indicate that XPro1595 attenuates ocular hypertension-induced loss of RGCs globally throughout the retina.

A hallmark of glaucoma is the degeneration of RGC axons in the optic nerve posterior to the lamina cribrosa; therefore, we also investigated the capacity of XPro 1595 to protect axons. Analysis of optic nerve cross-sections showed a substantially larger number of RGC axon fibers with normal morphology in XPro1595treated eyes compared with vehicle-treated controls (Fig. 3D-F). The latter displayed extensive axon degeneration including disarray of fascicular organization and degradation of myelin sheaths. Quantitative analysis confirmed that XPro1595 promoted marked protection of RGC axons (80\%: 79,917 \pm 1574 axons/nerve, mean \pm SEM, $n=6$ ) compared with vehicle treatment (45\%: 45,345 \pm 7583 axons/nerve, $n=6$; Fig. $3 H$; Table 1).

To assess whether XPro1595 reduced intraocular pressure, which could account for its neuroprotective effect, we measured eye pressure every other day after glaucoma induction. Our results show that XPro1595 administration did not reduce eye pressure and that the pressure elevations among XPro1595-treated and vehicle-treated groups were similar (Table 2). Given that the rate of RGC death is proportional to ocular hypertension, the similar increase in intraocular pressure among groups allowed for reliable comparison of the neuroprotective effect of XPro 1595 versus vehicle. Our results demonstrate that XPro1595 protects both RGC soma and axons, without altering eye pressure, suggesting a prominent role for soluble $\mathrm{TNF} \alpha$ in glaucoma downstream ocular hypertension.

\section{Ocular hypertension-induced TNF $\alpha$ triggers CP-AMPAR activity in RGCs}

To investigate whether soluble TNF $\alpha$ modulates CP-AMPAR in glaucoma, we used an in situ cobalt $\left(\mathrm{Co}^{2+}\right)$ permeability assay (Aurousseau et al., 2012). $\mathrm{Co}^{2+}$ is transported into neurons expressing CP-AMPAR in the plasma membrane, but it does not permeate through other $\mathrm{Ca}^{2+}$ channels or NMDA receptors (Hagiwara and Byerly, 1981; Mayer and Westbrook, 1987). Following $\mathrm{Co}^{2+}$ precipitation, the appearance of a dark brown color is visualized only in neurons containing CP-AMPAR. In noninjured retinas, $\mathrm{Co}^{2+}$ accumulation was detected solely in cells of the inner nuclear layer (INL; Fig. 4A), previously identified as horizontal and AII amacrine cells (Osswald et al., 2007). Remarkably, ocular hypertension induced massive $\mathrm{Co}^{2+}$ accumulation in the ganglion cell layer (GCL), where RGC soma are located, and in the inner plexiform layer (IPL), where dendrites are present (Fig. 4B). Displaced amacrine cells account for $\sim 40-50 \%$ of the total number of neurons in the GCL (Perry, 1981; Schlamp et 

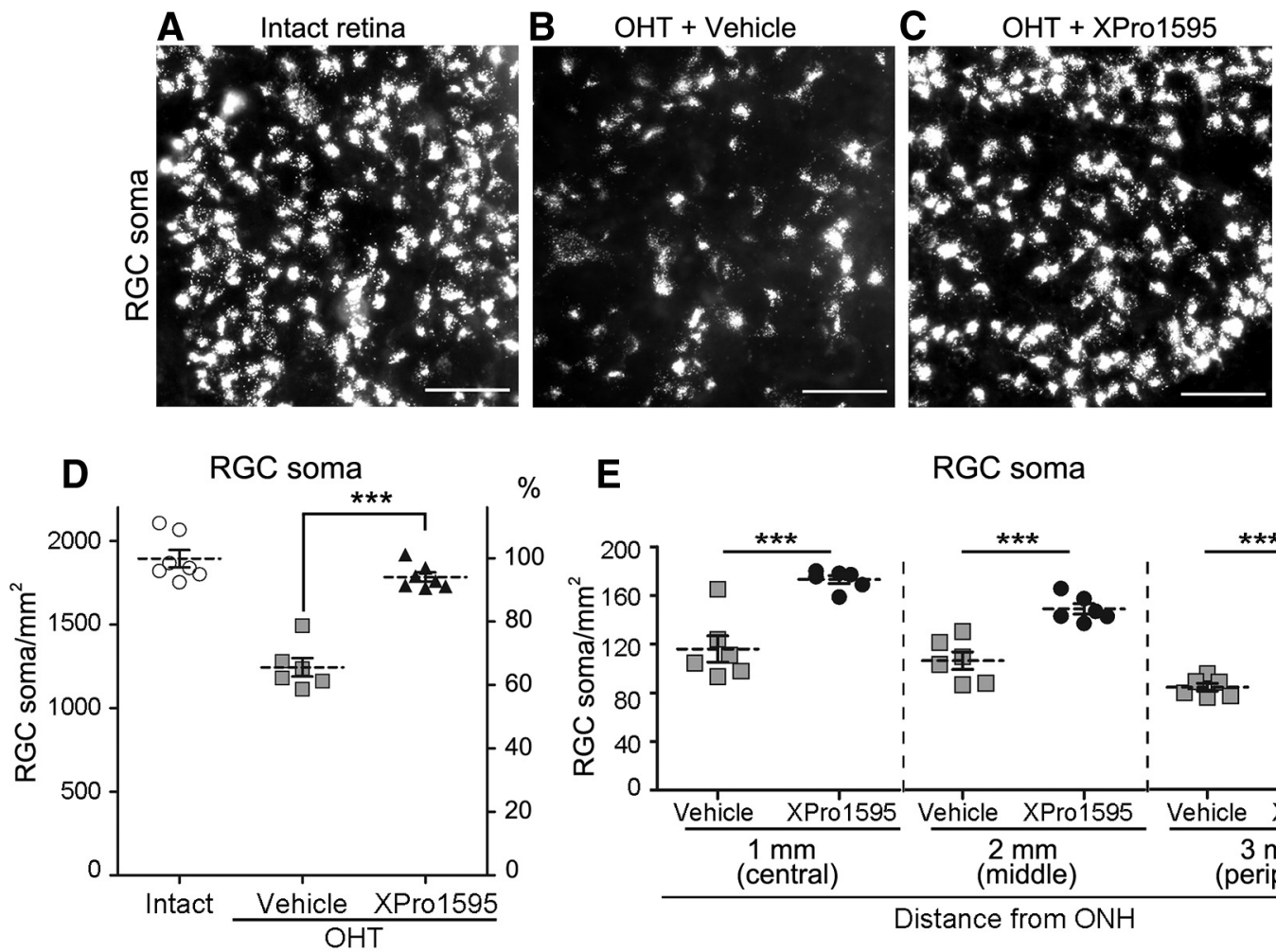

E

RGC soma

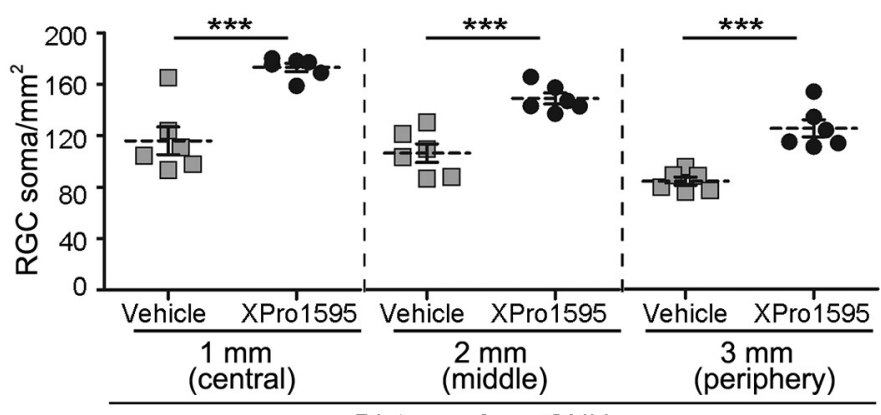

Distance from $\mathrm{ONH}$
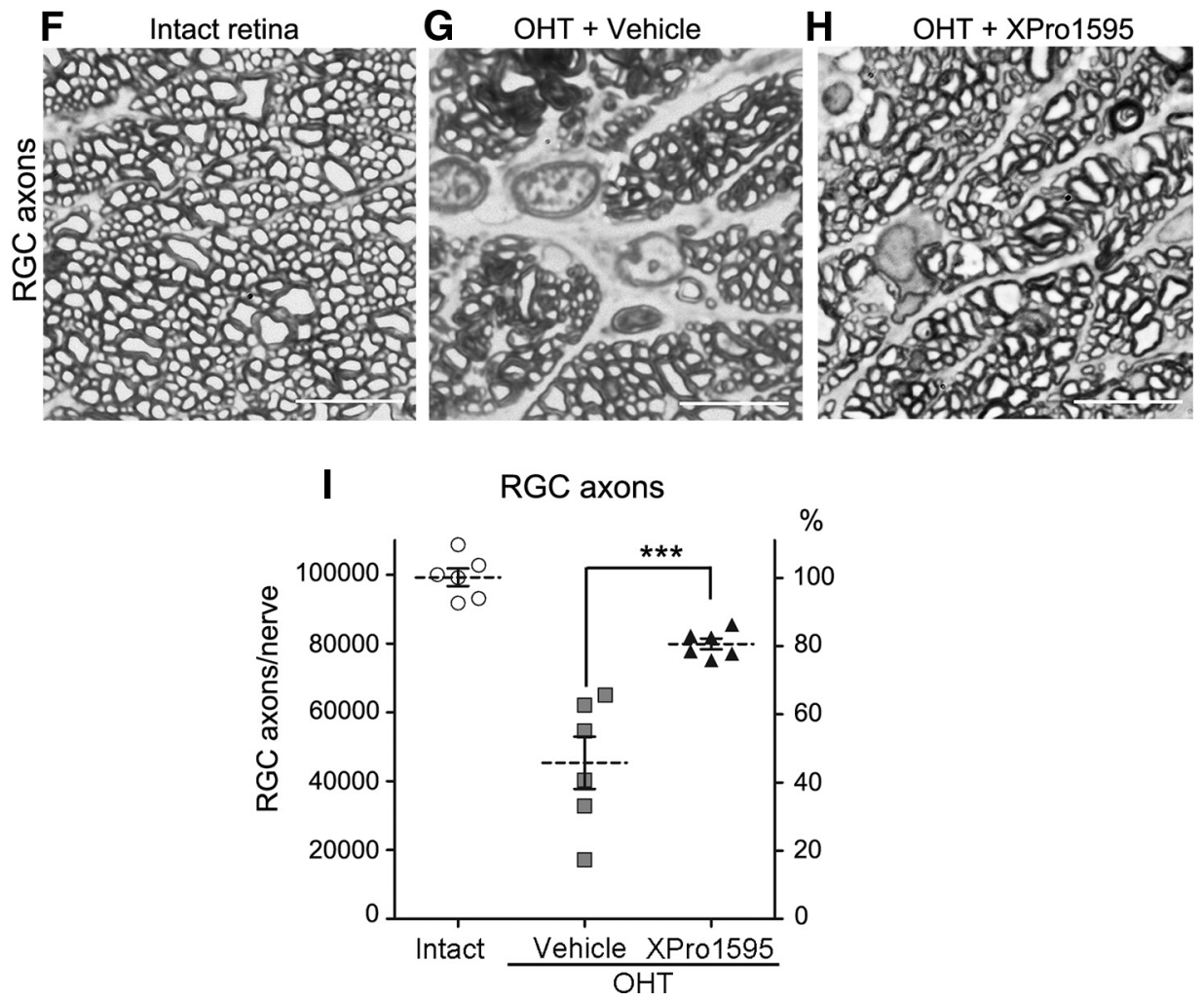

Figure 3. Inhibition of soluble TNF $\alpha$ promotes RGC soma and axon protection. A-C, Flat-mounted retinas from eyes treated with XPro1595 displayed higher densities of Dil-positive RGCS compared with control retinas treated with vehicle at 3 weeks after ocular hypertension (OHT). Scale bars, $50 \mu \mathrm{m}$. D, Quantitative analysis confirmed that XPro 1595 (black triangles) promoted significant RGC soma compared with control eyes treated with vehicle (gray squares). $\boldsymbol{E}$, XPro1595-mediated survival was equivalent in all retinal regions examined: $1 \mathrm{~mm}$ (central), $2 \mathrm{~mm}$ (middle), and $3 \mathrm{~mm}$ (periphery) from the optic nerve head in each quadrant, accounting for the protection of 33,29, and 33\% of all RGCs, respectively. Values are expressed as the mean \pm SEM ( $n=6$, Student's t test, $\left.{ }^{* * *} p<0.001\right) . F-H, 0$ ptic nerves in XPro1595-treated eyes contained more RGC axon fibers with normal morphology compared with control eyes. Scale bars, $10 \mu \mathrm{m}$. I, Quantitative analysis confirmed that XPro1595 (black triangles) promoted significant RGC axon survival compared with control eyes treated with vehicle (gray squares). The densities of RGC soma and axons in intact, nonglaucomatous Brown Norway rat retinas are shown as reference (white circles, 100\% survival). Values are expressed as the mean \pm SEM (intact, $n=7 ; \mathrm{XPr} 01595, n=7 ;$ vehicle, $n=$ $6 ;$ ANOVA, $\left.{ }^{* * *} p<0.001\right)$. 
Table 1. Role of XPro1595 on RGC survival

\begin{tabular}{|c|c|c|c|c|c|c|}
\hline \multirow[b]{2}{*}{ Treatment } & \multirow[b]{2}{*}{$N$} & \multicolumn{2}{|c|}{$\mathrm{RGC}$ soma $/ \mathrm{mm}^{2}$ retina } & \multirow[b]{2}{*}{$N$} & \multicolumn{2}{|c|}{ RGC axons/optic nerve } \\
\hline & & Mean \pm SEM & $\%$ & & Mean \pm SEM & $\%$ \\
\hline N/A (intact control) & 7 & $1894 \pm 52$ & 100 & 6 & $99279 \pm 2555$ & 100 \\
\hline XPro1595 & 7 & $1785 \pm 27$ & 94 & 6 & $79917 \pm 1574$ & 81 \\
\hline Vehicle & 6 & $1244 \pm 55$ & 66 & 6 & $45345 \pm 7583$ & 46 \\
\hline
\end{tabular}

XPro1595 promotes RGC soma and axon survival. Values are expressed as mean \pm SEM. Intact, nontreated, noninjured control retinas or optic nerves are used as reference $(100 \%)$.

Table 2. IOP elevation in glaucomatous eyes

\begin{tabular}{|c|c|c|c|c|c|c|c|}
\hline \multirow{2}{*}{$\begin{array}{l}\text { Time after } \\
\text { OHT surgery }\end{array}$} & \multirow[b]{2}{*}{ Treatment } & \multirow[b]{2}{*}{$N$} & \multicolumn{3}{|c|}{ Mean IOP $(\mathrm{mmHg}) \pm$ SEM } & \multicolumn{2}{|c|}{ Peak IOP (mmHg) } \\
\hline & & & Glaucoma & Control & Difference & Glaucoma & Control \\
\hline \multirow[t]{4}{*}{3 weeks } & Vehicle & 15 & $36 \pm 0.6$ & $24 \pm 0.2$ & $12 \pm 0.6$ & $39 \pm 0.6$ & $26 \pm 1.2$ \\
\hline & XPro1595 & 15 & $37 \pm 0.7$ & $25 \pm 0.2$ & $12 \pm 0.6$ & $41 \pm 1.7$ & $26 \pm 0.6$ \\
\hline & GIKY 52466 & 7 & $35 \pm 0.8$ & $24 \pm 0.5$ & $11 \pm 0.7$ & $39 \pm 1.4$ & $26 \pm 0.5$ \\
\hline & PhTx 343 & 5 & $35 \pm 1.0$ & $24 \pm 0.6$ & $11 \pm 1.4$ & $39 \pm 1.3$ & $26 \pm 0.6$ \\
\hline
\end{tabular}

IOP elevation in glaucomatous eyes treated with different compounds. Mean and peak IOP elevations for each cohort of rats exposed to 3 weeks of ocular hypertension (OHT) after treatment with XPro1595, GIKY 52466, PhTX 343, or vehicle ( $n=5-15 /$ group).

al., 2013) hence we performed colabeling with the RGC-specific marker RBPMS (Kwong et al., 2010; Rodriguez et al., 2013) to selectively label RGCs in intact and glaucomatous retinas (Fig. $4 C, D)$. Colocalization of $\mathrm{Co}^{2+}$ precipitate with RBPMS confirmed that $\mathrm{Co}^{2+}$ accumulated in RGCs (Fig. $4 E, F$ ).

To test whether soluble TNF $\alpha$ was required for increased CPAMPAR levels leading to $\mathrm{Co}^{2+}$ accumulation, XPro1595 was injected intraocularly 2 weeks after glaucoma induction and $\mathrm{Co}^{2+}$ staining was performed 1 week later. Figure $4 G$ shows that XPro1595 strongly inhibited $\mathrm{Co}^{2+}$ uptake by RGCs. Treatment with GYKI 52466, a noncompetitive AMPAR antagonist (Mellor, 2010), or Philantotoxin 343 (PhTx 343), a polyamine-derived compound that selectively antagonizes CP-AMPAR (Strømgaard et al., 2005), effectively blocked $\mathrm{Co}^{2+}$ uptake (Fig. $4 H, I$ ). These data indicate that $\mathrm{Co}^{2+}$ accumulation in RGCs was due to selective flux through CP-AMPAR and rule out the contribution of other glutamate receptors. We conclude that, in glaucoma, soluble TNF $\alpha$ triggers the CP-AMPAR activity detected in RGCs.

\section{Retinal AMPAR GluA2 subunit is fully edited at the $Q / R$ site in glaucoma}

The $\mathrm{Ca}^{2+}$ permeability of AMPAR varies depending on whether the GluA2 subunit is present and, if so, whether it has undergone mRNA editing. GluA2 mRNA editing switches an uncharged amino acid glutamine $(\mathrm{Q})$ to a positively charged arginine (R), and as a result, $\mathrm{Ca}^{2+}$ cannot be transported due to electrostatic repulsion by the arginine residues lining the AMPAR pore (Burnashev et al., 1992). We then asked whether GluA2 mRNA transcripts were edited as a mechanism accounting for AMPAR $\mathrm{Ca}^{2+}$ permeability in glaucoma. To this end, a $254 \mathrm{bp}$ amplicon of rat GluA2 incorporating the Q/R site was amplified from cDNA generated by RT-PCR using retinal mRNA. Taking advantage of the presence of an additional $B b v l$ restriction site unique to the unedited GluA2 (Q) sequence, digestion of the PCR product resulted in a distinct band pattern consistent with GluA2 control plasmid coding for arginine at the $\mathrm{Q} / \mathrm{R}$ site in both intact and glaucomatous retinas (Fig. $5 A, B$ ). In addition, parallel sequencing of the amplicon confirmed that GluA2 transcripts from both control and glaucoma samples encoded an arginine residue at the Q/R site (Fig. 5C-F). Our data demonstrate that the GluA2 subunit is fully edited in glaucoma, and strongly suggest that GluA2 editing is not the cause for increased CP-AMPAR expression.

\section{GluA2 expression in RGCs is downregulated by ocular hypertension}

Reduced expression or absence of the GluA2 subunit results in AMPARs that are permeable to $\mathrm{Ca}^{2+}$ (Dingledine et al., 1999). To determine whether TNF $\alpha$-mediated loss of GluA2 could account for increased CP-AMPAR activity in RGCs, we examined GluA2 levels in glaucomatous retinas. Our results show that ocular hypertension triggers a gradual and substantial decrease of both retinal GluA2 mRNA and protein (Fig. $6 A-D$ ). Subcellular fractionation of membrane and cytosolic fractions confirmed a significant reduction of membrane-associated GluA2 in hypertensive retinas (Fig. $6 E, F$ ). The enrichment of each fraction for membrane or cytosolic proteins was confirmed using $\mathrm{Na}^{+} / \mathrm{K}^{+}$ ATPase or GAPDH, respectively (Fig. 6E). To establish whether GluA2 was downregulated in RGCs, retinal immunofluorescence was performed. A striking reduction of GluA2 labeling was observed in the GCL of retinas subjected to ocular hypertension (Fig. 6G,H). Costaining of GluA2 with the RGC-specific marker RBPMS confirmed that loss of GluA2 labeling reflected protein downregulation and not death of RGCs (Fig. 6G,H). We conclude that RGC levels of GluA2 are markedly reduced in glaucoma.

\section{CP-AMPAR blockade promotes RGC soma and axon survival} To determine whether TNF $\alpha$ mediates RGC death by modulating plasma membrane levels of CP-AMPAR, we examined the neuroprotective effect of AMPAR channel blockers. Our data show that a single injection of GYKI 52466 or PhTx 343 promoted RGC soma and axon protection at 3 weeks after ocular hypertension compared with vehicle-treated retinas (Fig. 7A-F). Quantitative analysis was performed blinded to treatment and confirmed that GYKI 52466 and PhTx 343 resulted in striking RGC soma survival ( $88 \%$ and $91 \%$, respectively) compared with vehicle $(65 \%$; Fig. $7 G$ ). Similarly, quantification of RGC axons in optic nerve cross sections revealed robust axonal protection by GYKI 52466 (70\%) and PhTx 343 (73\%) with respect to vehicle-treated controls $(46 \%$; Fig. $7 H)$. Consistent with the idea that the primary site of degeneration in glaucoma is at the level of the axon, we observed more pronounced axon loss than soma loss. Nonetheless, both GYKI 52466 and PhTx protected a similar proportion of RGC soma and axons. Our data demonstrate a critical role for CP-AMPAR in RGC death in glaucoma.

\section{Discussion}

Despite data linking TNF $\alpha$ with glaucomatous neurodegeneration, little is known about the form of TNF $\alpha$ that promotes RGC death and its underlying mechanism of action. In this regard, the data presented here, using a well characterized rat glaucoma model reveal several novel findings. First, we show that ocular hypertension rapidly stimulates production of TNF $\alpha$ by Müller cells and microglia/macrophages, and increases TNFR1 and TNFR2 expression in RGCs. Second, we demonstrate that XPro1595, an inhibitor of soluble TNF $\alpha$, effectively protects RGC soma and axons. Third, we show that TNF $\alpha$ stimulates the expression of CP-AMPAR in RGCs, a response that does not depend on defects in GluA2 mRNA editing but reflects selective downregulation of GluA2 by these neurons. Last, our results demonstrate that CP-AMPAR blockers promote robust RGC survival supporting a critical role for non-NMDA glutamate receptors in glaucomatous damage. Collectively, this study identifies a novel mechanism by which glia-derived soluble TNF $\alpha$ modulates neuronal CP-AMPA function leading to RGC death, 

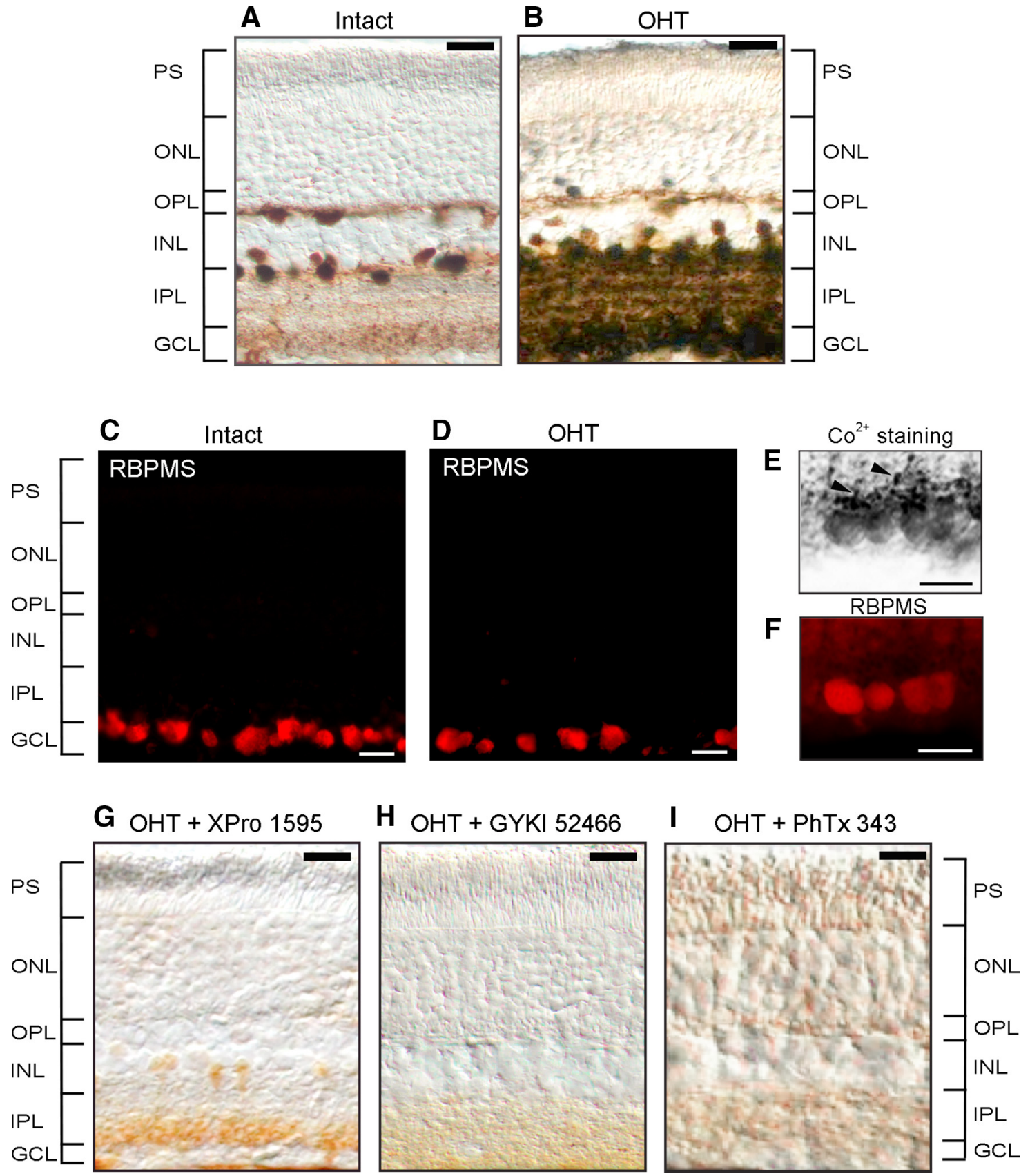

Figure 4. TNF $\alpha$ stimulates the expression of CP-AMPAR by RGCS. $A, \mathrm{C}^{2+}$ accumulation in noninjured (intact) retinas, was detected solely in cells of the INL previously identified as horizontal and All amacrine cells. $\boldsymbol{B}$, Ocular hypertension (OHT) promoted $\mathrm{Co}^{2+}$ accumulation in the $\mathrm{GCL}$ and inner plexiform layer, where $\mathrm{RGC}$ soma and dendrites are located ( $n=6-8 / \mathrm{group}$ ). $\boldsymbol{C}, \mathbf{D}$, Immunohistochemistry with RBPMS allowed identification of RGCS in both intact and glaucomatous retinas. $E, F$, Colocalization of $\mathrm{C}^{2+}$ precipitate with RBPMS confirmed that $\mathrm{C}_{0}{ }^{2+}$ accumulated in RGC soma and dendrites (arrowheads). G-I, Glaucoma-induced $\mathrm{C}^{2+}$ uptake was blocked by XPro1595, GYKI 52466, and PhTx 343 ( $n=6-8 /$ group). Scale bars, $20 \mu \mathrm{m}$. PS, Photoreceptor segments; ONL, outer nuclear layer; OPL: outer plexiform layer.

and establishes a critical link between neuroinflammation and cell damage in glaucoma.

Elevated intraocular pressure (IOP) is a critical risk factor for developing glaucoma and it is the cornerstone of research into glaucoma pathophysiology. Here, ocular hypertension was induced by injection of hypertonic saline into episcleral veins blocking aqueous humor outflow at the iridocorneal angle and trabecular meshwork, the sites of drainage obstruction in most forms of human glaucoma. In this model, there is an excellent linear correlation between intraocular pressure and neuronal damage (Morrison et al., 1997, 2005, 2015). Inner retinal atrophy, optic nerve degeneration, and optic nerve head remodeling in this model are similar to those observed in human glaucoma (Morrison et al., 2015), thus it is an excellent in vivo paradigm of glaucomatous damage. Limitations of this model are the challenging microsurgical skill to successfully cannulate the small episcleral veins, the fluctuation in IOP responses often observed in rodent models of aqueous outflow obstruction, and the risk of anterior chamber deepening and corneal opacity in some animals (Morrison et al., 2015). Another consideration is the anatomical difference between the rat and the human optic nerve head including the composition of the lamina cribrosa (Morrison et al., 1995). Nonetheless, the cost-effective use of rats and their docile nature, allowing measurement of IOP in awake animals with only 

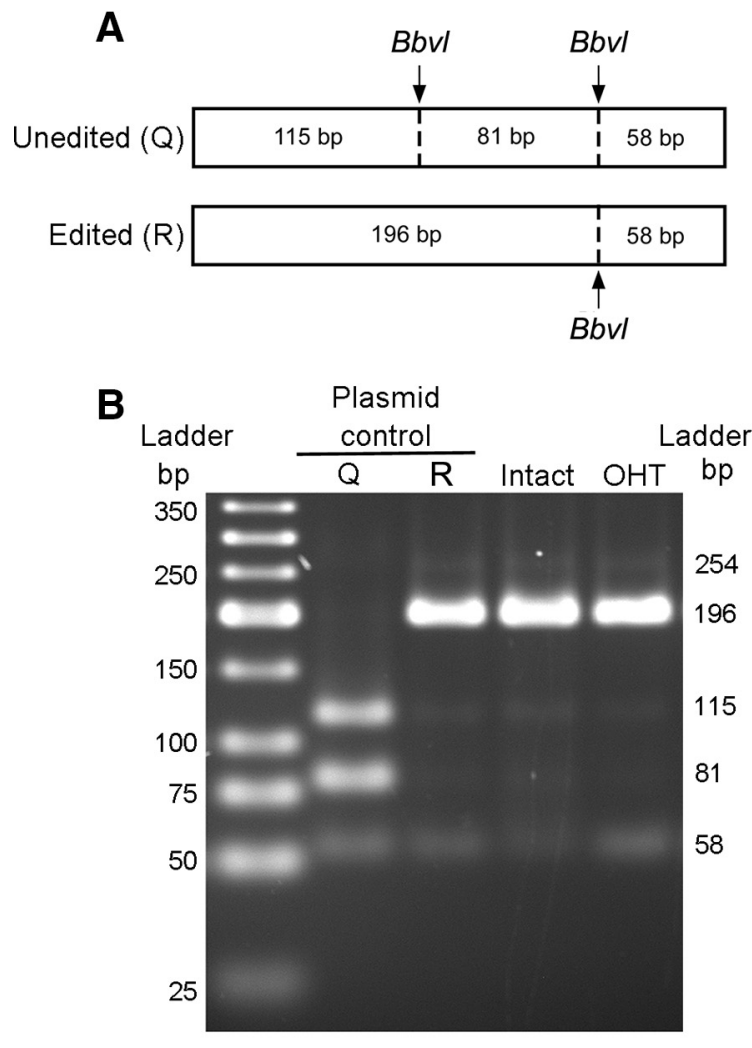

C

Intact retina

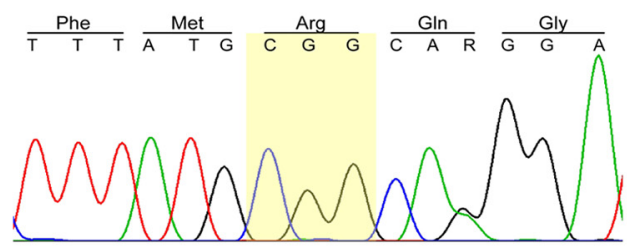

D

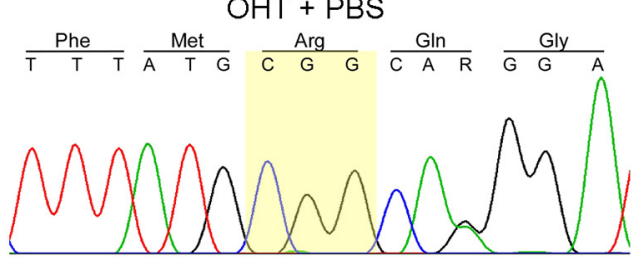

E
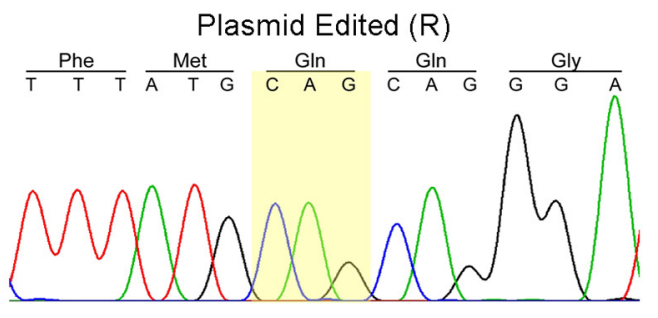

$\mathbf{F}$

Plasmid Unedited (Q)

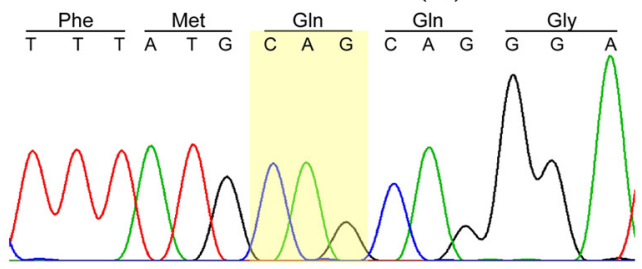

Figure 5. AMPAR GluA2 subunits are fully edited at the $Q / R$ site in glaucoma. $A$, The presence of an additional $B b v /$ restriction site at the $Q / R$ site was used to determine the editing state of $G$ luA2. $B b v /$ digestion of a $254 \mathrm{bp}$ amplicon comprising the $Q / R$ site led to the appearance of two or three fragments, corresponding to the presence of edited (R) and unedited ( $Q$ ) GluA2 forms, respectively. $\boldsymbol{B}$, The Bbvl digestion pattern of the GluA2 amplicon amplified from cDNA generated from intact and glaucomatous retina matched that of the fully edited GluA2 (R) plasmid control. C $\boldsymbol{F}$, Sanger sequencing shows that both uninjured (intact) and glaucomatous (OHT) retinas encoded for arginine (CGG) at the Q/R site (highlighted in yellow).

topical anesthesia, enhance the attractive features of this useful glaucoma model system.

During glaucoma, chronically reactive glial cells are thought to become a sustained source of proinflammatory cytokines (Seitz et al., 2013). Our data demonstrate that Iba1-positive microglia/macrophages are a source of TNF $\alpha$ in ocular hypertensive eyes. TNF $\alpha$ expression was observed primarily in microglia/macrophages with amoeboid shape, characteristic of a reactive state, rather than in resting cells with ramified morphology. This finding is consistent with previous reports showing TNF $\alpha$ expression in microglia from human glaucomatous optic nerve head (Yuan and Neufeld, 2001) and rat retinas subjected to episcleral vein cauterization (Roh et al., 2012). Of interest, high-dose irradiation leading to reduced microglial activation, and presumably decreased levels of proinflammatory mediators, attenuated RGC degeneration in a mouse model of inherited pigmentary glaucoma (Bosco et al., 2012; Howell et al., 2012). Moreover, our results demonstrate that Müller cells, the most abundant glial cell type in the retina, upregulate TNF $\alpha$ in response to increased eye pressure. Excitotoxic damage has also been shown to rapidly increase NF $\kappa \mathrm{B}$ (nuclear factor $\kappa \mathrm{B}$ ) activation and TNF $\alpha$ production by Müller cells (Lebrun-Julien et al., 2009b). It is currently unknown how ocular hypertension stimulates TNF $\alpha$ output by reactive glia but it might involve mechanisms dependent on isch- emia/hypoxia. For example, cultured microglia subjected to hypoxia release more TNF $\alpha$ and interleukin $1 \beta$ than cells exposed to normal oxygen levels (Sivakumar et al., 2011). Accumulation of toxic factors may also increase glia reactivity and subsequent neuroinflammation. Indeed, we have previously shown that the precursor form of nerve growth factor activates neurotrophin receptor $\mathrm{p} 75^{\mathrm{NTR}}$-dependent signaling mechanisms on Müller cells, leading to increased production of TNF $\alpha$ and subsequent RGC death (Lebrun-Julien et al., 2010).

The two active forms of TNF $\alpha$, soluble and transmembrane, play distinct biological roles. We used XPro1595 to block soluble $\mathrm{TNF} \alpha$ and to elucidate its role in glaucomatous neurodegeneration. XPro1595 is an engineered protein that selectively binds with soluble TNF $\alpha$ monomers to form inactive heterotrimers unable to interact with TNF $\alpha$ receptors. Therefore, XPro1595 eliminates signaling from soluble TNF $\alpha$ without interfering with the transmembrane form (Steed et al., 2003; Zalevsky et al., 2007). Our data demonstrate that XPro1595 effectively promotes RGC survival, without altering intraocular pressure. Given that both TNFR1 and TNFR2 are upregulated by RGCs during ocular hypertension, we speculate that blockade of soluble TNF $\alpha$ minimizes the detrimental effect of TNFR1 activation while preserving beneficial TNFR2-mediated signaling. Recent studies also reported a neuroprotective effect of XPro1595 in models of ex- 
perimental autoimmune encephalomyelitis, spinal cord injury, Parkinson's disease, and Huntington's disease, confirming a harmful role for soluble TNF $\alpha$ in neurodegenerative conditions (Brambilla et al., 2011; Barnum et al., 2014; Hsiao et al., 2014; Novrup et al., 2014). Etanercept, a drug that blocks both soluble and transmembrane $\mathrm{TNF} \alpha$, has been shown to protect RGCs in a rat glaucoma model (Roh et al., 2012). However, nonselective TNF $\alpha$ inhibitors, including etanercept, infliximab, and adalimumab, have been linked to serious adverse effects such as impaired host defense, autoimmunity, lupus, demyelination syndromes, and congestive heart failure (van Oosten et al., 1996; Keane et al., 2001; Lee et al., 2002; Shakoor et al., 2002; Slifman et al., 2003; Sfikakis, 2010). Collectively, these findings highlight the benefits of inhibiting soluble TNF $\alpha$ while preserving transmembrane TNF $\alpha$ function during neurodegeneration.

In physiological conditions, TNF $\alpha$ is an important modulator of synaptic plasticity by its ability to regulate AMPA receptor trafficking. In hippocampal pyramidal neurons, TNF $\alpha$ strengthens synapses by rapid exocytosis of AMPAR that lack or have low stoichiometric amounts of the GluA2 subunit thus enhancing intracellular $\mathrm{Ca}^{2+}$ rises (Ogoshi et al., 2005; Stellwagen et al., 2005). We found low levels of endogenous TNF $\alpha$ in the uninjured adult rat retina that correlated with sparse expression of CP-AMPAR. Using a $\mathrm{Co}^{2+}$ permeability assay applied to adult intact retinas, we confirmed that CP-AMPAR expression was restricted to inhibitory interneurons, horizontal and AII amacrine cells, as shown previously (Mørkve et al., 2002; Singer and Diamond, 2003; Veruki et al., 2003; Osswald et al., 2007). Although CP-AMPAR have been reported in acutely purified neonatal RGCs and can contribute to excitotoxicity (Park et al., 2015), CP-AMPAR have not been previously detected in adult RGCs. Remarkably, we show that ocular hypertension triggers robust CP-AMPAR upregulation in these neurons. Our finding that XPro1595 attenuates $\mathrm{Co}^{2+}$ accumulation in RGCs indicates that soluble TNF $\alpha$ contributes to the increase of CP-AMPAR. Our data suggest that while basal levels of TNF $\alpha$ are required for retinal homeostasis and neurotransmission, excess soluble TNF $\alpha$ results in CP-AMPAR upregulation and cell death in glaucoma.

Consistent with the idea that the primary site of degeneration in glaucoma is at the level of RGC axons, we found that all glaucomatous eyes had more pronounced axon loss than cell body loss. Interestingly, however, intravitreal injection of XPro1595 or CP-AMPAR blockers effectively protected a similar proportion
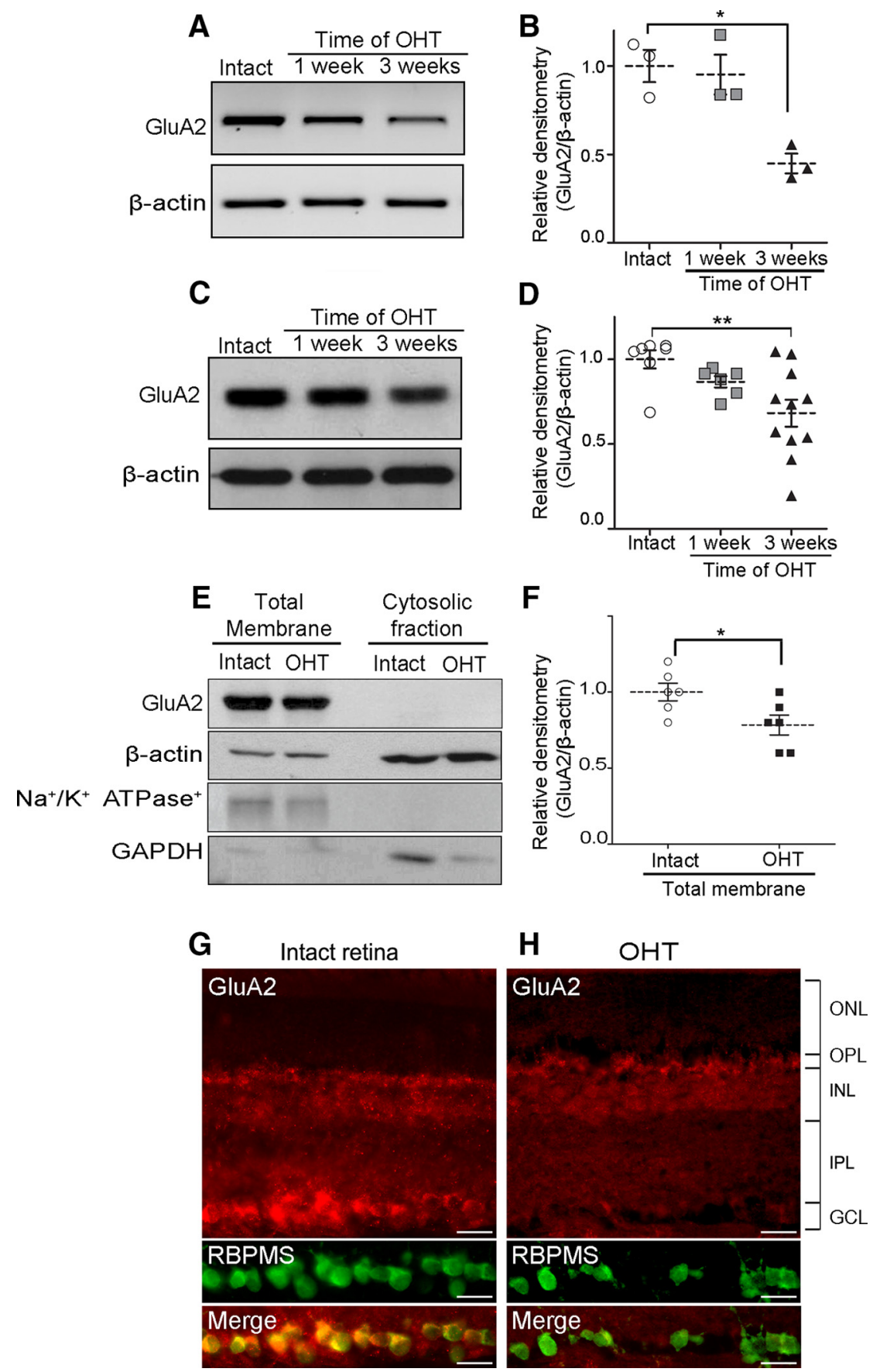

Figure 6. GluA2 is downregulated in RGCS subjected to ocular hypertension. $A$, RT-PCR analysis of glaucomatous retinas showed GluA2 $\mathrm{mRNA}$ downregulation after $\mathrm{OHT}$ induction compared with intact controls. $\boldsymbol{B}$, Densitometry analysis of amplification products with respect to $\beta$-actin controls confirmed GluA2 gene expression downregulation in glaucoma $\left(n=3\right.$, ANOVA, $\left.{ }^{*} p<0.05\right)$. C, Analysis of protein homogenates showed a decrease in retinal GluA2 levels after $\mathrm{OHT}$ induction. The bottom is the same blot probed with an antibody that recognizes $\beta$-actin to confirm equal protein loading. $\boldsymbol{D}$, Densitometry analysis of Western blots, showing the ratio of GluA2 relative to $\beta$-actin $\left(n=11\right.$, ANOVA, $\left.{ }^{* *} p<0.01\right)$. $\boldsymbol{E}$, Subcellular fractionation showed a decrease in membrane-associated GluA2 in hypertensive retinas. Enrichment of each fraction for membrane or cytosolic proteins was confirmed using $\mathrm{Na}^{+} / \mathrm{K}^{+}$ATPase or GAPDH, respectively $(\boldsymbol{F})$ Densitometry analysis revealed a significant decrease of GluA2 in the membrane fraction from ocular hypertensive ( $\mathrm{OHT}$ ) retinas compared with intact controls $\left(n=4\right.$, Student'st test, $\left.{ }^{*} p<0.05\right)$. G, H, Double-immunohistochemistry showed that GluA2 (red) colocalized with the RGC-specific marker RBPMS (green), and that GluA2 protein expression decreased in glaucomatous (OHT) retinas. Scale bar, $50 \mu \mathrm{m}$. ONL, Outer nuclear layer; OPL: outer plexiform layer. 

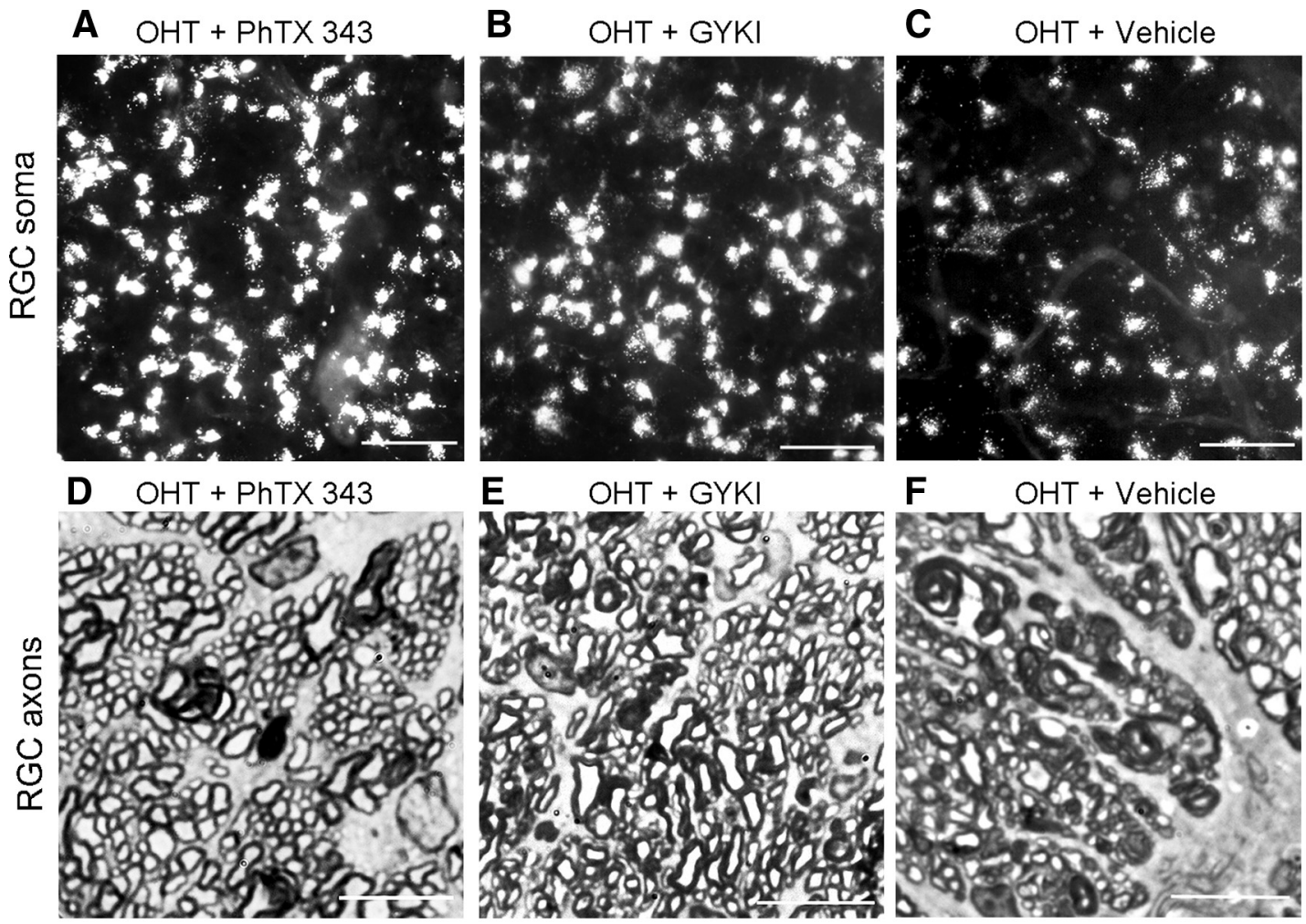

G

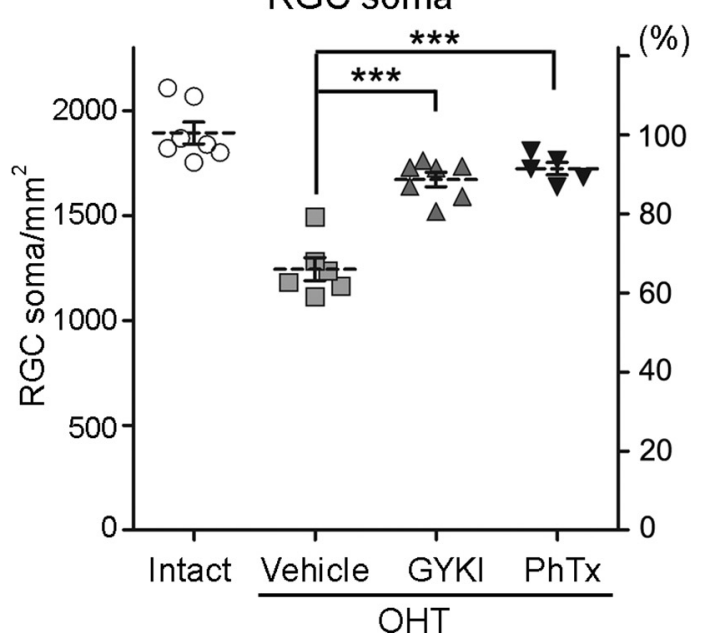

$\mathrm{H}$

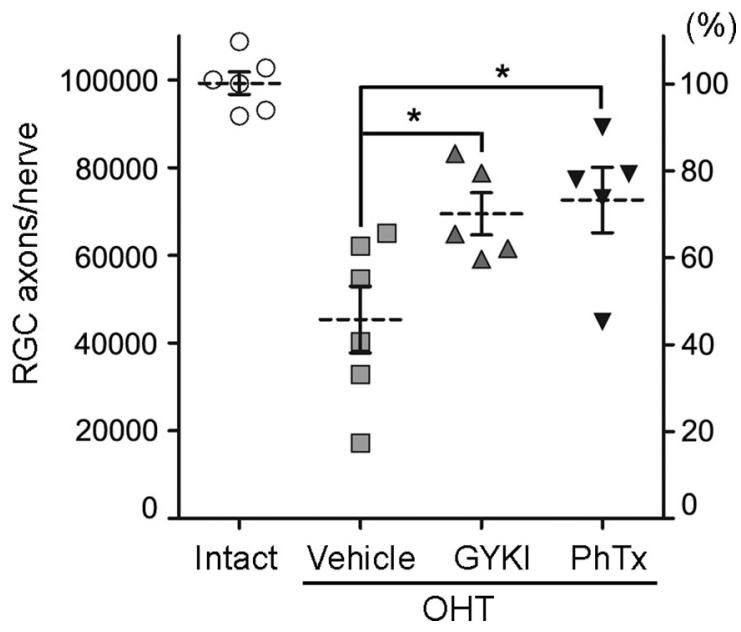

Figure 7. CP-AMPAR blockade promotes RGC survival. A-C, Flat-mounted retinas from eyes treated with PhTX343 or GYKI 52466 displayed higher densities of Dil-positive RGCs compared with control retinas treated with vehicle at 3 weeks after ocular hypertension (OHT). Scale bars, $50 \mu \mathrm{m}$. D-F, Optic nerves from PhTX343- or GYKI 52466-treated eyes contained many more RGC axon fibers with normal morphology compared with control eyes. Scale bars, $10 \mu \mathrm{m} . \mathbf{G}, H$, Quantitative analysis confirmed that PhTX343 (black triangles) and GYKI 52466 (dark gray triangles) promoted significant RGC soma and axon survival compared with control eyes treated with vehicle (light gray squares). The densities of RGC soma and axons in intact, nonglaucomatous Brown Norway rat

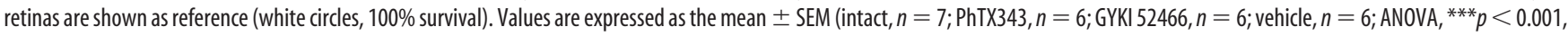
$\left.{ }^{*} p<0.05\right)$.

First, ocular hypertension-induced stress at the optic nerve head inflicts an initial injury to the axon, which although still undefined in nature, might involve energy or nutrient supply deficits and activation of local degenerative pathways (Calkins, 2012; Nickells et al., 2012). Our study suggests that a rapid consequence of axonal damage is upregulation of TNF $\alpha$ receptors at RGC soma, which become responsive to glia-derived soluble $\operatorname{TNF} \alpha$, and in turn, upregulate cell surface CP-AMPAR. Increased $\mathrm{Ca}^{2+}$ entry to RGC soma via CP-AMPAR is likely to stimulate signaling cascades that exacerbate axonal degeneration. Indeed, excessive cytosolic $\mathrm{Ca}^{2+}$ activates $\mathrm{Ca}^{2+}$-dependent calpains and caspases that degrade components of the RGC axonal cytoskeleton slowing or blocking axonal transport (Crish and Calkins, 2011). $\mathrm{Ca}^{2+}$ overload may also lead to oxidative stress impairing mitochondrial function which, in addition to decreasing the capacity of mitochondria to buffer $\mathrm{Ca}^{2+}$, might aggravate axonal damage by disabling $\mathrm{Na}^{+} / \mathrm{K}^{+}$ion pumps causing electrical failure of RGC axons (Tsutsui and Stys, 2013). Of interest, functional AMPA receptors are found at the internodal axolemma and in oligodendrocyte somata (McDonald et al., 1998; Ouardouz et al., 2009), 
therefore it is plausible that TNF $\alpha$ produced locally in the optic nerve might upregulate $\mathrm{CP}$-AMPAR in RGC axons leading to loss of ionic homeostasis, lethal $\mathrm{Ca}^{2+}$ overload and axonal loss.

How do AMPAR become permeable to divalent ions in glaucoma? One possibility is defective GluA2 mRNA editing. Typically, the change from an uncharged amino acid glutamine $(\mathrm{Q})$ to a positively charged arginine (R) in GluA2 is sufficient to confer $\mathrm{Ca}^{2+}$ impermeability (Burnashev et al., 1992). Abnormal mRNA processing failing to complete this process will result in a $\mathrm{Ca}^{2+}$ permeable AMPAR pore. Our findings show that retinal GluA2 is fully edited in glaucoma, ruling out a post-transcriptional editing defect as a mechanism by which AMPARs become divalent permeable. A second possibility is a decrease in GluA2 leading to AMPARs that are permeable to divalent ions. Using biochemical and immunohistochemical analyses, we demonstrate that GluA2 expression is substantially downregulated in RGCs subjected to ocular hypertension. GluA2-lacking CP-AMPAR are traditionally thought of as $\mathrm{Ca}^{2+}$ permeable channels that are blocked by exogenous and endogenous polyamines, while GluA2-containing receptors are impermeable to $\mathrm{Ca}^{2+}$ and lack polyamine sensitivity (Bowie et al., 1999; Dingledine et al., 1999). Of interest, a third class of AMPAR characterized by divalent permeability and weak sensitivity to polyamine block has been proposed to exist in some CNS regions including the retina (Bowie, 2012). Indeed, although divalent permeability through AMPAR in horizontal and AII amacrine cells was effectively blocked with the polyamine derivative PhTX 343 before eye opening, these AMPAR became insensitive to PhTX 343 by postnatal day 14 (Osswald et al., 2007). Our data show that PhTX 343 blocks divalent permeability through CP-AMPAR, and in doing so, promotes robust RGC survival in glaucomatous eyes. These observations suggest that adult retinal neurons exposed to ocular hypertension revert to an immature phenotype characterized by CP-AMPAR that are permeable to divalent cations and sensitive to polyamine block. Our findings also reveal the potential to use of polyamine-derived compounds as neuroprotective agents for glaucoma.

The molecular mechanisms by which $\mathrm{TNF} \alpha$ regulates $\mathrm{CP}$ AMPAR are not well understood. Early work using hippocampal neuron cultures indicated that increased cell surface AMPAR expression mediated by TNF $\alpha$, insulin, or glycine requires phosphatidylinositol 3 kinase activity (Passafaro et al., 2001; Man et al., 2003; Stellwagen et al., 2005). Our data suggest that TNF $\alpha$ mediated downregulation or loss of GluA2 might be a potential regulatory mechanism to increase divalent ion influx through AMPAR leading to RGC death in glaucoma. Although the process by which $\mathrm{TNF} \alpha$ might regulate GluA2 levels is currently unknown, it is established that neuronal GluA2 expression is not stable, but rather closely regulated by activity, drugs, seizures, or ischemic damage often accompanied by proinflammatory cytokine release (Pollard et al., 1993; Fitzgerald et al., 1995; Prince et al., 1995; Gorter et al., 1997; Liu and Cull-Candy, 2000). During forebrain ischemia, GluA2 expression is selectively downregulated in CA1 hippocampal neurons destined to die, a process that involves suppression of GluA2 promoter activity by repressor element-1 silencing transcription factor (Pellegrini-Giampietro et al., 1992; Calderone et al., 2003). A recent study demonstrated that the interaction of GluA2 and $\mathrm{N}$-ethylmaleimide-sensitive fusion protein, an ATPase involved in stabilization of GluA2 at the membrane, is disrupted by Polo-like kinase-2 leading to extensive loss of cell-surface GluA2 in primary hippocampal neu- rons (Evers et al., 2010). It will be of future interest to assess whether these processes are modulated by $\operatorname{TNF} \alpha$.

In conclusion, using multiple complementary techniques we demonstrate a crucial role of glia-derived soluble TNF $\alpha$ in glaucomatous neurodegeneration. Importantly, our data identify a novel and important mechanism of soluble TNF $\alpha$-induced damage involving GluA2 downregulation and increased CP-AMPAR leading to RGC death. These findings expand our understanding of the molecular basis of RGC damage during neuroinflammation and might have implications in the design of neuroprotective strategies for glaucoma.

\section{References}

Alexopoulou L, Kranidioti K, Xanthoulea S, Denis M, Kotanidou A, Douni E, Blackshear PJ, Kontoyiannis DL, Kollias G (2006) Transmembrane TNF protects mutant mice against intracellular bacterial infections, chronic inflammation and autoimmunity. Eur J Immunol 36:2768-2780. CrossRef Medline

Almasieh M, Zhou Y, Kelly ME, Casanova C, Di Polo A (2010) Structural and functional neuroprotection in glaucoma: role of galantaminemediated activation of muscarinic acetylcholine receptors. Cell Death Dis 1:e27. CrossRef Medline

Almasieh M, MacIntyre JN, Pouliot M, Casanova C, Vaucher E, Kelly ME, Di Polo A (2013) Acetylcholinesterase inhibition promotes retinal vasoprotection and increases ocular blood flow in experimental glaucoma. Invest Ophthalmol Vis Sci 54:3171-3183. CrossRef Medline

Arnett HA, Mason J, Marino M, Suzuki K, Matsushima GK, Ting JP (2001) TNF[alpha] promotes proliferation of oligodendrocyte progenitors and remyelination. Nat Neurosci 4:1116-1122. CrossRef Medline

Aurousseau MR, Osswald IK, Bowie D (2012) Thinking of Co2+-staining explant tissue or cultured cells? How to make it reliable and specific. Eur J Neurosci 35:1201-1207. CrossRef Medline

Balaiya S, Edwards J, Tillis T, Khetpal V, Chalam KV (2011) Tumor necrosis factor-alpha (TNF- $\alpha$ ) levels in aqueous humor of primary open angle glaucoma. Clin Ophthalmol 5:553-556. CrossRef Medline

Barnum CJ, Chen X, Chung J, Chang J, Williams M, Grigoryan N, Tesi RJ, Tansey MG (2014) Peripheral administration of the selective inhibitor of soluble tumor necrosis factor (TNF) XPro1595 attenuates nigral cell loss and glial activation in 6-OHDA hemiparkinsonian rats. J Parkinsons Dis 4:349-360. CrossRef Medline

Beattie EC, Stellwagen D, Morishita W, Bresnahan JC, Ha BK, Von Zastrow M, Beattie MS, Malenka RC (2002) Control of synaptic strength by glial TNFalpha. Science 295:2282-2285. CrossRef Medline

Bosco A, Crish SD, Steele MR, Romero CO, Inman DM, Horner PJ, Calkins DJ, Vetter ML (2012) Early reduction of microglia activation by irradiation in a model of chronic glaucoma. PLoS One 7:e43602. CrossRef Medline

Bowie D (2012) Redefining the classification of AMPA-selective ionotropic glutamate receptors. J Physiol 590:49-61. CrossRef Medline

Bowie D, Bähring R, Mayer ML (1999) Block of kainate and AMPA receptors by polyamines and arthropod toxins. In: Handbook of experimental pharmacology; ionotropic glutamate receptors in the CNS (JPaM H, ed), pp 251-373. Berlin: Springer.

Brambilla R, Ashbaugh JJ, Magliozzi R, Dellarole A, Karmally S, Szymkowski DE, Bethea JR (2011) Inhibition of soluble tumour necrosis factor is therapeutic in experimental autoimmune encephalomyelitis and promotes axon preservation and remyelination. Brain 134:2736-2754. CrossRef Medline

Burnashev N, Monyer H, Seeburg PH, Sakmann B (1992) Divalent ion permeability of AMPA receptor channels is dominated by the edited form of a single subunit. Neuron 8:189-198. CrossRef Medline

Calderone A, Jover T, Noh KM, Tanaka H, Yokota H, Lin Y, Grooms SY, Regis R, Bennett MV, Zukin RS (2003) Ischemic insults derepress the gene silencer REST in neurons destined to die. J Neurosci 23:2112-2121. Medline

Calkins DJ (2012) Critical pathogenic events underlying progression of neurodegeneration in glaucoma. Prog Retin Eye Res 31:702-719. CrossRef Medline

Canault M, Peiretti F, Mueller C, Kopp F, Morange P, Rihs S, Portugal H, Juhan-Vague I, Nalbone G (2004) Exclusive expression of transmem- 
brane TNF- $\alpha$ in mice reduces the inflammatory response in early lipid lesions of aortic sinus. Atherosclerosis 172:211-218. CrossRef Medline

Caprioli J (1997) Neuroprotection of the optic nerve in glaucoma. Acta Ophthalmol Scand 75:364-367. Medline

Crish SD, Calkins DJ (2011) Neurodegeneration in glaucoma: progression and calcium-dependent intracellular mechanisms. Neuroscience 176: 1-11. CrossRef Medline

Dingledine R, Borges K, Bowie D, Traynelis SF (1999) The glutamate receptor ion channels. Pharmacol Rev 51:7-61. Medline

Evers DM, Matta JA, Hoe HS, Zarkowsky D, Lee SH, Isaac JT, Pak DT (2010) Plk2 attachment to NSF induces homeostatic removal of GluA2 during chronic overexcitation. Nat Neurosci 13:1199-1207. CrossRef Medline

Ferguson AR, Christensen RN, Gensel JC, Miller BA, Sun F, Beattie EC, Bresnahan JC, Beattie MS (2008) Cell death after spinal cord injury is exacerbated by rapid TNF\{alpha\}-induced trafficking of GluR2-lacking AMPARs to the plasma membrane. J Neurosci 28:11391-11400. CrossRef Medline

Fitzgerald LW, Deutch AY, Gasic G, Heinemann SF, Nestler EJ (1995) Regulation of cortical and subcortical glutamate receptor subunit expression by antipsychotic drugs. J Neurosci 15:2453-2461. Medline

Fontaine V, Mohand-Said S, Hanoteau N, Fuchs C, Pfizenmaier K, Eisel U (2002) Neurodegenerative and neuroprotective effects of tumor necrosis factor (TNF) in retinal ischemia: opposite roles of TNF receptor 1 and TNF receptor 2. J Neurosci 22:RC216. Medline

Georgopoulos G, Andreanos D, Liokis N, Papakonstantinou D, Vergados J, Theodossiadis G (1997) Risk factors in ocular hypertension. Eur J Ophthalmol 7:357-363. Medline

Gorter JA, Petrozzino JJ, Aronica EM, Rosenbaum DM, Opitz T, Bennett MV, Connor JA, Zukin RS (1997) Global ischemia induces downregulation of Glur2 mRNA and increases AMPA receptor-mediated Ca2+ influx in hippocampal CA1 neurons of gerbil. J Neurosci 17:6179-6188. Medline

Hagiwara S, Byerly L (1981) Calcium channel. Annu Rev Neurosci 4:69125. CrossRef Medline

Holtmann MH, Neurath MF (2004) Differential TNF-signaling in chronic inflammatory disorders. Curr Mol Med 4:439-444. CrossRef Medline

Howell GR, Soto I, Zhu X, Ryan M, Macalinao DG, Sousa GL, Caddle LB, MacNicoll KH, Barbay JM, Porciatti V, Anderson MG, Smith RS, Clark AF, Libby RT, John SW (2012) Radiation treatment inhibits monocyte entry into the optic nerve head and prevents neuronal damage in a mouse model of glaucoma. J Clin Invest 122:1246-1261. CrossRef Medline

Hsiao HY, Chiu FL, Chen CM, Wu YR, Chen HM, Chen YC, Kuo HC, Chern $\mathrm{Y}$ (2014) Inhibition of soluble tumor necrosis factor is therapeutic in Huntington's disease. Hum Mol Genet 23:4328 -4344. CrossRef Medline

Ierna MX, Scales HE, Mueller C, Lawrence CE (2009) Transmembrane tumor necrosis factor alpha is required for enteropathy and is sufficient to promote parasite expulsion in gastrointestinal helminth infection. Infect Immun 77:3879-3885. CrossRef Medline

Imai Y, Kohsaka S (2002) Intracellular signaling in M-CSF-induced microglia activation: role of Iba1. Glia 40:164-174. CrossRef Medline

Jeon CJ, Strettoi E, Masland RH (1998) The major cell populations of the mouse retina. J Neurosci 18:8936-8946. Medline

Keane J, Gershon S, Wise RP, Mirabile-Levens E, Kasznica J, Schwieterman WD, Siegel JN, Braun MM (2001) Tuberculosis associated with infliximab, a tumor necrosis factor alpha-neutralizing agent. N Engl J Med 345:1098-1104. Medline

Kwong JM, Caprioli J, Piri N (2010) RNA binding protein with multiple splicing: a new marker for retinal ganglion cells. Invest Ophthalmol Vis Sci 51:1052-1058. CrossRef Medline

Lebrun-Julien F, Morquette B, Douillette A, Saragovi HU, Di Polo A (2009a) Inhibition of p75NTR in glia potentiates TrkA-mediated survival of injured retinal ganglion cells. Mol Cell Neurosci 40:410-420. CrossRef Medline

Lebrun-Julien F, Duplan L, Pernet V, Osswald I, Sapieha P, Bourgeois P, Dickson K, Bowie D, Barker PA, Di Polo A (2009b) Excitotoxic death of retinal neurons in vivo occurs via a non-cell-autonomous mechanism. J Neurosci 29:5536-5545. CrossRef Medline

Lebrun-Julien F, Bertrand MJ, De Backer O, Stellwagen D, Morales CR, Di Polo A, Barker PA (2010) ProNGF induces TNF $\alpha$-dependent death of retinal ganglion cells through a p75NTR non-cell-autonomous signaling pathway. Proc Natl Acad Sci U S A 107:3817-3822. CrossRef Medline

Lee JH, Slifman NR, Gershon SK, Edwards ET, Schwieterman WD, Siegel JN, Wise RP, Brown SL, Udall JN Jr, Braun MM (2002) Life-threatening histoplasmosis complicating immunotherapy with tumor necrosis factor alpha antagonists infliximab and etanercept. Arthritis Rheum 46:25652570. CrossRef Medline

Leonoudakis D, Zhao P, Beattie EC (2008) Rapid tumor necrosis factor $\alpha$-induced exocytosis of glutamate receptor 2-lacking AMPA receptors to extrasynaptic plasma membrane potentiates excitotoxicity. J Neurosci 28:2119-2130. CrossRef Medline

Liu SQ, Cull-Candy SG (2000) Synaptic activity at calcium-permeable AMPA receptors induces a switch in receptor subtype. Nature 405:454458. CrossRef Medline

Mac Nair CE, Fernandes KA, Schlamp CL, Libby RT, Nickells RW (2014) Tumor necrosis factor alpha has an early protective effect on retinal ganglion cells after optic nerve crush. J Neuroinflammation 11:194. CrossRef Medline

Man HY, Wang Q, Lu WY, Ju W, Ahmadian G, Liu L, D’Souza S, Wong TP, Taghibiglou C, Lu J, Becker LE, Pei L, Liu F, Wymann MP, MacDonald JF, Wang YT (2003) Activation of PI3-kinase is required for AMPA receptor insertion during LTP of mEPSCs in cultured hippocampal neurons. Neuron 38:611-624. CrossRef Medline

Marin I, Kipnis J (2013) Learning and memory ... and the immune system. Learn Mem 20:601-606. CrossRef Medline

Mayer ML, Westbrook GL (1987) Permeation and block of N-methyl-Daspartic acid receptor channels by divalent cations in mouse cultured central neurones. J Physiol 394:501-527. CrossRef Medline

McDonald JW, Althomsons SP, Hyrc KL, Choi DW, Goldberg MP (1998) Oligodendrocytes from forebrain are highly vulnerable to AMPA/kainate receptor-mediated excitotoxicity. Nat Med 4:291-297. CrossRef Medline

Mellor IR (2010) The AMPA receptor as a therapeutic target: current perspectives and emerging possibilities. Future Med Chem 2:877-891. CrossRef Medline

Mørkve SH, Veruki ML, Hartveit E (2002) Functional characteristics of non-NMDA-type ionotropic glutamate receptor channels in AII amacrine cells in rat retina. J Physiol 542:147-165. CrossRef Medline

Morrison J, Farrell S, Johnson E, Deppmeier L, Moore CG, Grossmann E (1995) Structure and composition of the rodent lamina cribrosa. Exp Eye Res 60:127-135. CrossRef Medline

Morrison JC, Moore CG, Deppmeier LM, Gold BG, Meshul CK, Johnson EC (1997) A rat model of chronic pressure-induced optic nerve damage. Exp Eye Res 64:85-96. CrossRef Medline

Morrison JC, Johnson EC, Cepurna W, Jia L (2005) Understanding mechanisms of pressure-induced optic nerve damage. Prog Retin Eye Res 24: 217-240. CrossRef Medline

Morrison JC, Cepurna WO, Johnson EC (2015) Modeling glaucoma in rats by sclerosing aqueous outflow pathways to elevate intraocular pressure. Exp Eye Res. Advance online publication. Retrieved May 21, 2015. CrossRef Medline

Moss ML, Jin SL, Milla ME, Bickett DM, Burkhart W, Carter HL, Chen WJ, Clay WC, Didsbury JR, Hassler D, Hoffman CR, Kost TA, Lambert MH, Leesnitzer MA, McCauley P, McGeehan G, Mitchell J, Moyer M, Pahel G, Rocque W, et al. (1997) Cloning of a disintegrin metalloproteinase that processes precursor tumor-necrosis factor- $\alpha$. Nature 385:733-736. CrossRef Medline

Mueller C, Corazza N, Trachsel-Løseth S, Eugster HP, Bühler-Jungo M, Brunner T, Imboden MA (1999) Noncleavable transmembrane mouse tumor necrosis factor- $\alpha(\mathrm{TNF} \alpha)$ mediates effects distinct from those of wild-type TNF $\alpha$ in vitro and in vivo. J Biol Chem 274:38112-38118. CrossRef Medline

Nakazawa T, Nakazawa C, Matsubara A, Noda K, Hisatomi T, She H, Michaud N, Hafezi-Moghadam A, Miller JW, Benowitz LI (2006) Tumor necrosis factor- $\alpha$ mediates oligodendrocyte death and delayed retinal ganglion cell loss in a mouse model of glaucoma. J Neurosci 26:1263312641. CrossRef Medline

Nickells RW, Howell GR, Soto I, John SW (2012) Under pressure: cellular and molecular responses during glaucoma, a common neurodegeneration with axonopathy. Annu Rev Neurosci 35:153-179. CrossRef Medline

Novrup HG, Bracchi-Ricard V, Ellman DG, Ricard J, Jain A, Runko E, Lyck L, Yli-Karjanmaa M, Szymkowski DE, Pearse DD, Lambertsen KL, Bethea JR (2014) Central but not systemic administration of XPro1595 is therapeutic following moderate spinal cord injury in mice. J Neuroinflammation 11:159. CrossRef Medline

Ogoshi F, Yin HZ, Kuppumbatti Y, Song B, Amindari S, Weiss JH (2005) Tumor necrosis-factor-alpha (TNF- $\alpha$ ) induces rapid insertion of $\mathrm{Ca} 2+$-permeable 
$\alpha$-amino-3-hydroxyl-5-methyl-4-isoxazole-propionate (AMPA)/kainate (Ca$\mathrm{A} / \mathrm{K}$ ) channels in a subset of hippocampal pyramidal neurons. Exp Neurol 193: 384-393. CrossRef Medline

Oikonomou N, Harokopos V, Zalevsky J, Valavanis C, Kotanidou A, Szymkowski DE, Kollias G, Aidinis V (2006) Soluble TNF mediates the transition from pulmonary inflammation to fibrosis. PLoS One 1:e108. CrossRef Medline

Olleros ML, Guler R, Corazza N, Vesin D, Eugster HP, Marchal G, Chavarot P, Mueller C, Garcia I (2002) Transmembrane TNF induces an efficient cell-mediated immunity and resistance to mycobacterium bovis bacillus Calmette-Guérin infection in the absence of secreted TNF and lymphotoxin- $\alpha$. J Immunol 168:3394-3401. CrossRef Medline

Olleros ML, Guler R, Vesin D, Parapanov R, Marchal G, Martinez-Soria E, Corazza N, Pache JC, Mueller C, Garcia I (2005) Contribution of transmembrane tumor necrosis factor to host defense against mycobacterium bovis bacillus Calmette-Guerin and mycobacterium tuberculosis infections. Am J Pathol 166:1109-1120. CrossRef Medline

Osswald IK, Galan A, Bowie D (2007) Light triggers expression of philanthotoxin-insensitive $\mathrm{Ca} 2+$-permeable AMPA receptors in the developing rat retina. J Physiol 582:95-111. CrossRef Medline

Ouardouz M, Coderre E, Zamponi GW, Hameed S, Yin X, Trapp BD, Stys PK (2009) Glutamate receptors on myelinated spinal cord axons: II. AMPA and GluR5 receptors. Ann Neurol 65:160-166. CrossRef Medline

Park YH, Mueller BH 2nd, McGrady NR, Ma HY, Yorio T (2015) AMPA receptor desensitization is the determinant of AMPA receptor mediated excitotoxicity in purified retinal ganglion cells. Exp Eye Res 132:136-150. CrossRef Medline

Pasparakis M, Alexopoulou L, Episkopou V, Kollias G (1996) Immune and inflammatory responses in TNF alpha-deficient mice: a critical requirement for TNF alpha in the formation of primary B cell follicles, follicular dendritic cell networks and germinal centers, and in the maturation of the humoral immune response. J Exp Med 184:1397-1411. CrossRef Medline

Passafaro M, Piëch V, Sheng M (2001) Subunit-specific temporal and spatial patterns of AMPA receptor exocytosis in hippocampal neurons. Nat Neurosci 4:917-926. CrossRef Medline

Pellegrini-Giampietro DE, Zukin RS, Bennett MV, Cho S, Pulsinelli WA (1992) Switch in glutamate receptor subunit gene expression in CA1 subfield of hippocampus following global ischemia in rats. Proc Natl Acad Sci U S A 89:10499-10503. CrossRef Medline

Perry VH (1981) Evidence for an amacrine cell system in the ganglion cell layer of the rat retina. Neuroscience 6:931-944. CrossRef Medline

Pollard H, Héron A, Moreau J, Ben-Ari Y, Khrestchatisky M (1993) Alterations of the GluR-B AMPA receptor subunit flip/flop expression in kainate-induced epilepsy and ischemia. Neuroscience 57:545-554. CrossRef Medline

Pribiag H, Stellwagen D (2014) Neuroimmune regulation of homeostatic synaptic plasticity. Neuropharmacology 78:13-22. CrossRef Medline

Prince HK, Conn PJ, Blackstone CD, Huganir RL, Levey AI (1995) Downregulation of AMPA receptor subunit GluR2 in amygdaloid kindling. J Neurochem 64:462-465. Medline

Rodriguez AR, de Sevilla Müller LP, Brecha NC (2014) The RNA binding protein RBPMS is a selective marker of ganglion cells in the mammalian retina. J Comp Neurol 522:1411-1443. CrossRef Medline

Roh M, Zhang Y, Murakami Y, Thanos A, Lee SC, Vavvas DG, Benowitz LI, Miller JW (2012) Etanercept, a widely used inhibitor of tumor necrosis factor- $\alpha$ (TNF- $\alpha)$, prevents retinal ganglion cell loss in a rat model of glaucoma. PLoS One 7:e40065. CrossRef Medline

Sawada H, Fukuchi T, Tanaka T, Abe H (2010) Tumor necrosis factor- $\alpha$ concentrations in the aqueous humor of patients with glaucoma. Invest Ophthalmol Vis Sci 51:903-906. CrossRef Medline

Schlamp CL, Montgomery AD, Mac Nair CE, Schuart C, Willmer DJ, Nickells RW (2013) Evaluation of the percentage of ganglion cells in the ganglion cell layer of the rodent retina. Mol Vis 19:1387-1396. Medline

Seitz R, Ohlmann A, Tamm ER (2013) The role of Müller glia and microglia in glaucoma. Cell Tissue Res 353:339-345. CrossRef Medline

Sfikakis PP (2010) The first decade of biologic TNF antagonists in clinical practice: lessons learned, unresolved issues and future directions. Curr Dir Autoimmun 11:180-210. CrossRef Medline

Shakoor N, Michalska M, Harris CA, Block JA (2002) Drug-induced sys- temic lupus erythematosus associated with etanercept therapy. Lancet 359:579-580. CrossRef Medline

Singer JH, Diamond JS (2003) Sustained Ca2 + entry elicits transient postsynaptic currents at a retinal ribbon synapse. J Neurosci 23:10923-10933. Medline

Sivakumar V, Foulds WS, Luu CD, Ling EA, Kaur C (2011) Retinal ganglion cell death is induced by microglia derived pro-inflammatory cytokines in the hypoxic neonatal retina. J Pathol 224:245-260. CrossRef Medline

Slifman NR, Gershon SK, Lee JH, Edwards ET, Braun MM (2003) Listeria monocytogenes infection as a complication of treatment with tumor necrosis factor alpha-neutralizing agents. Arthritis Rheum 48:319-324. CrossRef Medline

Soto I, Howell GR (2014) The complex role of neuroinflammation in glaucoma. Cold Spring Harb Perspect Med 4:a017269. CrossRef Medline

Steed PM, Tansey MG, Zalevsky J, Zhukovsky EA, Desjarlais JR, Szymkowski DE, Abbott C, Carmichael D, Chan C, Cherry L, Cheung P, Chirino AJ, Chung HH, Doberstein SK, Eivazi A, Filikov AV, Gao SX, Hubert RS, Hwang M, Hyun L, et al. (2003) Inactivation of TNF signaling by rationally designed dominant-negative TNF variants. Science 301:1895-1898. CrossRef Medline

Stellwagen D, Malenka RC (2006) Synaptic scaling mediated by glial TNF- $\alpha$. Nature 440:1054-1059. CrossRef Medline

Stellwagen D, Beattie EC, Seo JY, Malenka RC (2005) Differential regulation of AMPA receptor and GABA receptor trafficking by tumor necrosis factor- $\alpha$. J Neurosci 25:3219-3228. CrossRef Medline

Strømgaard K, Jensen LS, Vogensen SB (2005) Polyamine toxins: development of selective ligands for ionotropic receptors. Toxicon 45:249-254. CrossRef Medline

Tezel G (2013) Immune regulation toward immunomodulation for neuroprotection in glaucoma. Curr Opin Pharmacol 13:23-31. CrossRef Medline

Tezel G, Yang X, Yang J, Wax MB (2004) Role of tumor necrosis factor receptor-1 in the death of retinal ganglion cells following optic nerve crush injury in mice. Brain Res 996:202-212. CrossRef Medline

Tezel G, Yang X, Luo C, Cai J, Powell DW (2012) An astrocyte-specific proteomic approach to inflammatory responses in experimental rat glaucoma. Invest Ophthalmol Vis Sci 53:4220-4233. CrossRef Medline

Tham YC, Li X, Wong TY, Quigley HA, Aung T, Cheng CY (2014) Global prevalence of glaucoma and projections of glaucoma burden through 2040: a systematic review and meta-analysis. Ophthalmology 121:20812090. CrossRef Medline

Tsutsui S, Stys PK (2013) Metabolic injury to axons and myelin. Exp Neurol 246:26-34. CrossRef Medline

van Oosten BW, Barkhof F, Truyen L, Boringa JB, Bertelsmann FW, von Blomberg BM, Woody JN, Hartung HP, Polman CH (1996) Increased MRI activity and immune activation in two multiple sclerosis patients treated with the monoclonal anti-tumor necrosis factor antibody cA2. Neurology 47:1531-1534. CrossRef Medline

Veruki ML, Mørkve SH, Hartveit E (2003) Functional properties of spontaneous EPSCs and non-NMDA receptors in rod amacrine (AII) cells in the rat retina. J Physiol 549:759-774. CrossRef Medline

Voigt T (1986) Cholinergic amacrine cells in the rat retina. J Comp Neurol 248:19-35. CrossRef Medline

Xin X, Gao L, Wu T, Sun F (2013) Roles of tumor necrosis factor alpha gene polymorphisms, tumor necrosis factor alpha level in aqueous humor, and the risks of open angle glaucoma: a meta-analysis. Mol Vis 19:526-535. Medline

Yang X, Luo C, Cai J, Powell DW, Yu D, Kuehn MH, Tezel G (2011) Neurodegenerative and inflammatory pathway components linked to TNF$\alpha /$ TNFR1 signaling in the glaucomatous human retina. Invest Ophthalmol Vis Sci 52:8442-8454. CrossRef Medline

Yin HZ, Hsu CI, Yu S, Rao SD, Sorkin LS, Weiss JH (2012) TNF- $\alpha$ triggers rapid membrane insertion of $\mathrm{Ca} 2+$ permeable AMPA receptors into adult motor neurons and enhances their susceptibility to slow excitotoxic injury. Exp Neurol 238:93-102. CrossRef Medline

Yuan L, Neufeld AH (2001) Activated microglia in the human glaucomatous optic nerve head. J Neurosci Res 64:523-532. CrossRef Medline

Zalevsky J, Secher T, Ezhevsky SA, Janot L, Steed PM, O’Brien C, Eivazi A, Kung J, Nguyen DH, Doberstein SK, Erard F, Ryffel B, Szymkowski DE (2007) Dominant-negative inhibitors of soluble TNF attenuate experimental arthritis without suppressing innate immunity to infection. J Immunol 179:1872-1883. CrossRef Medline 